\title{
The Impact of Human Capital on the Early Success of Necessity vs. \\ Opportunity-based Entrepreneurs
}

\section{Rui Baptista}

Brunel Business School, Brunel University, UK

and

CEG-IST, Instituto Superior Técnico, University of Lisbon, Portugal

\section{Murat Karaöz}

Department of Econometrics, Faculty of Economics and Administrative Sciences, Akdeniz University, Antalya, Turkey

\section{Joana Mendonça}

IN+ Center for Innovation, Technology and Policy Research, Instituto Superior Técnico, University of Lisbon

\begin{abstract}
This paper examines whether founders' backgrounds influence new firm survival in the early years after startup focusing in particular on the impact of unemploymentdriven entrepreneurship. For entrepreneurs who left their previous employment to found a new firm, both general and specific human capital play a key role in enhancing early survival chances. However, various forms of human capital have little effect on early survival of unemployment-driven entrepreneurs, who rely mostly on previous entrepreneurial experience to persevere. Results suggest that pre-entry capabilities play an important role in the early success of opportunity-based entrepreneurs, but have little influence on the early success of necessity-based ones.
\end{abstract}

Keywords: Entrepreneur Human capital; Pre-entry capabilities; New Firm Survival; Opportunity-based Entrepreneurship; Necessity-based Entrepreneurship. 


\section{Introduction}

Empirical studies of market selection indicate that entrants are heterogeneous and initial conditions influence subsequent success (see, for instance: Geroski et al., 2010). However, most of these studies develop and/or test theories focusing on the fit between firm characteristics and market conditions after those firms have entered markets, and often neglect the role played by the characteristics of founders.

It can be argued that the creation of new firms involves ex-ante selection, as the would-be entrepreneurs evaluate whether an opportunity can be turned into a business which is sufficiently profitable to offset the opportunity costs involved (Barnett et al., 2003; Stam et al., 2010). Two characteristics drive the entry decision: the munificence of opportunities and the availability of resources and capabilities. Research has attempted to develop a structure for theory-building and applied work about the role played by pre-entry resources and capabilities in driving both entry decisions and postentry performance (Helfat and Lieberman, 2002). Prior knowledge enables entrepreneurs to better recognize opportunities (Shane and Venkataraman, 2000) and gives them the ability to exploit them. This knowledge might be unique to entrepreneurs (Alvarez and Busenitz, 2001).

A central argument of this research is that the success of new organizations is fundamentally shaped by the pre-entry experiences of their founders. New organizations benefit from knowledge that was accumulated by their founders throughout their careers (Agarwal et al., 2004). The present paper examines the role played by the backgrounds of founders in influencing new firm survival in the critical early years after startup. In particular, we seek to examine the role played by human capital in influencing the early 
success of individuals who gave up their previous employment position in order to start a business as opposed to those who founded a business following an unemployment spell. It seems logical to expect that the former are significantly more likely to be starting a business in order to exploit a discovered opportunity (opportunity-based entrepreneurs), while the latter are more likely to be starting a business out of necessity (that is, due to the lack of satisfactory employment prospects - necessity-based entrepreneurs).

Research in labor economics has found that interrupted careers translate into depreciation of human capital stocks. We suggest that same might apply to entrepreneurs. Knowledge and skills acquired previously in the labor market are likely to depreciate during interruptions associated with unemployment spells, meaning that entrepreneurs who start firms out of unemployment are not only less likely to have recognized valuable opportunities, but also have less abilities (i.e. specific industry, finance or marketing knowledge, and organizational routines) to exploit them.

Based on the extant literature, we propose hypotheses concerning the contribution of different sources of entrepreneurial human capital ${ }^{1}$ to new firm survival in the early years after startup, and use data on founders' backgrounds to create measures of entrepreneurial human capital arising from these sources in order to test those hypotheses. In particular, we seek to establish whether different sources of entrepreneurial human capital play a different role in driving early survival for opportunity-based (i.e. previously employed) and necessity-based (i.e. previously unemployed) entrepreneurs.

\footnotetext{
${ }^{1}$ We distinguish between a variety of sources of founder human capital: formal education; work experience; industry-specific experience; managerial experience and business ownership experience.
} 
By utilizing a longitudinal database linking firms, founders and employees, our study is able to examine a substantial number of startups and founders in a wide variety of sectors over several years. We contribute to the literature on new firm survival by taking into account the difference between opportunity and necessity (unemployment-driven) entrepreneurs, by using a wide variety of concepts of pre-entry human capital, and also by focusing on the early years in the life of firms.

This research has important implications for both practitioners and policy-makers. Founders play a fundamental role in determining the mission, strategy and organizational structure of new firms, ${ }^{2}$ so studies of new firm success - particularly in the first few years after startup - are fundamentally incomplete when founders' characteristics are overlooked. By looking at the chances of survival in the crucial early years after startup, this study provides insights for policy-makers on where to target government support to struggling young firms in order to maximize their contribution to overall competitiveness and employment.

The rest of the paper is organized as follows. The first part of section 2 reviews the literature establishing the influence of pre-entry capabilities and entrepreneurial human capital on the early success of new businesses and discusses a variety of ways in which entrepreneurs may accumulate specific human capital. In particular, we pay attention to differences between opportunity-based and unemployment-driven entrepreneurs, leading to the development of hypotheses with regard to their effect on new business survival. The second part of section 2 establishes the rationale for firm-level and industry controls. Section 3 presents the data and empirical strategy, while section 4

\footnotetext{
${ }^{2}$ Busenitz et al. (2003, p. 298) point out that "opportunities do not come to fruition without unique insights, perspectives, and interpretations by the founders, and are not transformed into wealth generation without organizing actions."
} 
displays and discusses the estimation results. Finally, section 5 offers some concluding remarks.

\section{Entrepreneurial Human Capital and Factors Influencing Firm Survival}

\subsection{Entrepreneurs' Backgrounds, Human Capital, and Survival}

The early years after startup are crucial for a firm's future. Virtually all studies in economics, management and organizational ecology find that younger firms confront higher probabilities of exit than their older counterparts (see, for instance, Santarelli and Vivarelli, 2007). The entrepreneurship literature often regards the first three years after startup as critical for the survival and success of new firms (Littunen et al., 1998). The Global Entrepreneurship Monitor (GEM) surveys of entrepreneurial activity define young businesses as firms that have been active for three and a half years or less. ${ }^{3}$ Geroski (1995, p. 424), points out that the "mechanism of displacement, which seems to be the most palpable consequence of entry, affects young, new firms more severely." In economics, market selection theories argue that firms are unsure about their efficiency prior to entry and learn from noisy signals provided by the market, leading to higher exit rates for recent startups firms than for older businesses (see, for instance, Jovanovic, 1982). Organizational ecologists speak of 'liability of newness' (Freeman et al., 1983) to describe the stylized fact that hazard rates decline monotonically with age as firms learn and adapt. Newly formed firms are less likely to be able to cope with environmental challenges than established organizations.

\footnotetext{
${ }^{3}$ According to the GEM definition, an enterprise is classified as a young business if it has paid salaries and wages for more than three months but for less than 42 months, and as an established business if it has paid salaries and wages for more than 42 months (Acs et al., 2005).
} 
The findings of economists and organizational ecologists suggest that the faster a firm learns about the fit between its resources and capabilities and market conditions, and the more able it is to adapt its competences to market requirements, the more likely it will survive the critical early years after startup. The availability of pre-entry knowledge about innovative capabilities, marketing and finance, and organizational routines should influence significantly the probability of survival in these critical early years, when firms have had little or no time to learn about the market. For new firms that do not result from diversification or joint venturing operations, pre-entry capabilities are associated primarily with the founders. Entrepreneurs with greater stocks of human capital will be less uncertain about their efficiency and will be able to learn faster about market conditions, therefore reducing the probability of early exit.

Brüderl et al. (1992) propose a framework distinguishing general and specific forms of entrepreneurial human capital, where general human capital includes education levels while specific human capital includes work experience and industry-specific experience. General and specific entrepreneurial human capital enhance the productivity of the founder-manager. We build on this distinction between general and specific forms of entrepreneurial human capital, associating them with specific phenomena that have been highlighted by entrepreneurship research (see, for instance, Dahl and Reichstein, 2007) as being related with the extent of opportunity identification and exploitation: spinouts, habitual entrepreneurship and, in particular, necessity-based vs. opportunity-based entrepreneurship.

Let us start with general human capital. It can be claimed that, through formal education, individuals acquire fundamental abilities to learn about markets and 
technology, and better recognize opportunities in the surrounding environment (Shane, 2000). Formal education also allows individuals to develop learning aptitudes and organizational skills to better organize to exploit those opportunities (Grant, 1996). Consequently, higher levels of education may give the entrepreneur higher ability to solve problems and make decisions regarding business development. Better educated entrepreneurs may also have better social networks, as a result of their longer stay in the education system, and that may be useful for the development of their businesses (Ucbasaran et al., 2008). Furthermore, better educated people should command higher average earnings as paid employees and, therefore, find it easier to fund their new business. In a comprehensive meta-analysis of studies of the returns to education for entrepreneurs, Van der Sluis et al. (2005) conclude that entrepreneurship performance, regardless of the performance measure used, is significantly and positively affected by formal education. We then expect that startups whose founder has a higher level of formal education have a greater probability of early survival.

People with more work experience and who have performed managerial duties are more likely to be in a better position to detect opportunities and raise capital, thus setting up larger and better-equipped businesses (Colombo et al., 2004). Knowledge of how to manage a business has a strong tacit form and can be gained informally by observing and making business decisions (Cooper et al., 1994). People with greater managerial experience are also more likely to have developed the necessary skills to organize new businesses (Shane, 2000). We therefore expect that startups whose founder has more years of work experience and, in particular, more years of managerial experience have a greater probability of early survival. 
Work experience is likely to be more useful for entrepreneurs when it takes place in the industry where the new firm is being started. In particular, entrepreneurs who forfeit employment in an established incumbent to create a startup in the same industry thereby creating a spinout ${ }^{4}$ - are more likely to achieve early success. People who have worked in the same industry for some time are likely to have accrued industry-specific human capital, meaning specialized market and technological knowledge, plus a network of professional and social contacts that facilitate the acquisition and management of both technical and human resources. In addition, people that have worked in the industry may have already established relationships with customers, suppliers, or other stakeholders. Founders with greater industry experience are likely to bring to their new firm specific knowledge about a wide range of issues, such as customer demand, products, technologies, suppliers and competitors (Helfat and Lieberman, 2002). Previous research has shown that experience of the business owner in the same industry in which a new business is started improves a firm's chances of survival and posterior firm performance (Bosma et al., 2004), even if such experience does not occur right before creating a startup. A period of time spent away from the industry may accelerate the depreciation of industry-specific human capital. Hence, while we expect that startups whose founder has more years of experience in the same industry should have a greater probability of early survival, startups whose founder was employed in the same industry right before startup (i.e. spinouts) will benefit more from industry-specific human capital.

\footnotetext{
${ }^{4}$ This definition of spinout is used by, among others, Agarwal et al (2004) and Klepper (2001, 2007) who uses the term "spinoff." While it may be deemed too inclusive (not all founders incorporated into this concept are necessarily exploiting opportunities discovered while working for their previous employer), any bias that may be introduced would counteract the effects supporting the hypotheses being tested.
} 
Specific human capital which is valuable for new business founders also manifests itself through entrepreneurial experience. Habitual entrepreneurs, meaning individuals who have started at least one business prior to founding a new one, ${ }^{5}$ include individuals who own several businesses simultaneously (portfolio entrepreneurs), as well as those who start a business subsequent to closing - or selling - another (serial entrepreneurs). Individuals who have accrued experience as business owners should possess higher accumulated levels of entrepreneurial human capital (Ucbasaran et al., 2003; Stam et al., 2008). In particular, they should have better managerial and technical skills, better networks of contacts, access to market-specific information and knowledge, and thus should be better equipped to discover and take advantage from new business opportunities (McGrath and MacMillan, 2000).

The value of human capital is likely to be different for serial and portfolio entrepreneurs. Serial entrepreneurs experience a break in between entrepreneurial events, which may last for an extended time (Amaral et al., 2011) and is likely to facilitate depreciation of the stock of specific human capital. Serial entrepreneurship is not necessarily associated with success, as it may result simply from a succession of business starts and closures. Portfolio entrepreneurs are less likely to face financial constraints to start a new firm than serial entrepreneurs, since they can deploy assets from their current firm (or firms) in the new startup. Recent research finds that serial entrepreneurs' performance in one venture enhances their performance in subsequent ventures only temporarily (Parker, 2013). Hence, in addition to a positive effect on survival chances from entrepreneurial experience, we expect that startups whose

\footnotetext{
${ }^{5}$ The present study is restricted to business owners who have started their businesses, therefore excluding those who have acquired or inherited ownership. We believe that, in considering only starters and not acquirers and inheritors, we may better approach the concept of entrepreneurship as understood by the management literature (Busenitz et al., 2003).
} 
founder owns one or more other businesses at the time of founding (portfolio entrepreneurs) have a greater probability of early survival.

The key element in our analysis is the distinction between the role played by human capital for opportunity-driven and unemployment-driven entrepreneurs. People who give up their current employment to start a new business incur an opportunity cost, so they are likely to be doing it due to the discovery of a promising business opportunity. People who are driven from unemployment into starting a business are likely to be doing it in order to make ends meet. Unemployment is a powerful driver of new firm creation. Founding a new firm may be an alternative to uncertain future career prospects or even an "escape from unemployment" (Storey, 1991). The empirical evidence highlighting the role played by job losses in fostering new startups is quite robust (Storey and Jones, 1987). If unemployment is the main incentive for setting up a business, there may not be time to look for good opportunities, make detailed plans, get appropriate funding, and seek advice. Hence, the chances of survival may be affected by selection occurring prior to startup.

Specific human capital and entrepreneurial abilities may erode with unemployment spells. Research in labor economics has found that interrupted careers translate into depreciation of human capital stocks. Mincer and Ofek (1982) established that interrupted work careers entail substantial wage reductions upon re-entry to the labor market, implying depreciation in human capital stocks. A substantial body of subsequent research has confirmed that human capital depreciates with time spent away from the workplace (see, for instance, Neuman and Weiss, 1995; Albrecht et al., 1999). Entrepreneurs' knowledge and skills acquired previously in the labor market (either as a 
business owner or a paid employee), while remaining of some value, gradually become less applicable as circumstances change, and interruptions associated with unemployment spells are likely to accelerate the depreciation of human capital stocks, meaning that entrepreneurs who start firms out of unemployment have less abilities (i.e. specific industry, finance or marketing knowledge, and organizational routines) to exploit them.

Empirical evidence on entrepreneurial careers has found that those who have entered self employment directly from unemployment exit to a higher extent than those who have entered directly from paid employment (Carrasco, 1999; Pfeiffer and Reize, 2000), and that new founders who were formerly unemployed have on average lower economic outcomes and a lower propensity to positively contribute to job creation (Andersson and Wadensjö, 2006). In view of this discussion, we formulate two key hypotheses:

H1: startups whose founder was unemployed right before founding have a lower probability of early survival.

H2: different forms of specific human capital of founders may have less positive impacts on firm survival probabilities for unemployment-driven entrepreneurs than for other entrepreneurs.

\subsection{Control Variables}

Mortality rates vary consistently across firms and industries, regardless of age. An extensive literature examining firm-level and industry-level determinants of new firm survival and growth has built up over the last decades. Comprehensive reviews of such determinants are provided by Santarelli and Vivarelli (2007), and Quatraro and Vivarelli 
(2013). We use the main results from this literature as guidance for the choice of controls used in this study.

The main firm-level determinant of survival is startup size. While the theoretical literature does not point towards a clear prediction of the effect of firm size on survival, empirical evidence supporting a "liability of smallness", meaning a negative relationship between hazard rates and size, is overwhelmingly unambiguous (Vivarelli, 2007). Therefore, we expect that firms that enter at a lower scale will have a lower probability of survival and use firm size at the time of founding as a control variable.

The resource-based view of the firm posits that the ability of firms to survive and to compete successfully is strongly influenced by the extent to which firms develop firmspecific assets, processes and routines which cannot be easily imitated by competitors (Peteraf, 1993; Eisenhardt and Martin, 2000). A number of authors have pointed out that a firm's knowledge resides in its human resources (Conner and Prahalad, 1996; Teece et al., 1997). Mata and Portugal (2002) argue that the level of the formal education held by a firm's workforce can be regarded as a measure, albeit imperfect, of firm-specific resources and capabilities. We therefore use the level of education of employees at the time of founding as a control.

The literature reports four main industry-level features influencing survival: i) economies of scale; ii) market concentration; ii) barriers to entry; and iv) industry growth (see, for instance, Mata and Portugal, 2002; Santarelli and Vivarelli, 2007). However, the effects of some of these factors are not always consistent in the theoretical and empirical literature (Vivarelli, 2007). Since the industry where the startup occurs 
clearly influences survival in a variety of ways, this study accounts for this influence by using industry fixed effects (i.e. industry dummies) in the empirical analysis.

Finally, we also control for the gender of the entrepreneur. Empirical findings on the success of ventures started by female entrepreneurs have been mixed. For instance, Cooper et al. (1994) find that firms with a male entrepreneur have a greater probability of high growth, but not of survival.

\section{Data and Methodology}

\subsection{Data}

We explore the Quadros de Pessoal (QP) database, a longitudinal matched employer-employee data set built from mandatory information submitted annually by all firms with at least one wage earner (excluding agriculture) to the Portuguese Ministry of Employment and Social Security covering the period from 1986 to 2005 . There are a minimum of 145,000 firms, 170,000 establishments and 2,000,000 workers and business owners included in each annual survey. Firms, establishments and individuals are fully cross-referenced through the use of a unique identification number, thus allowing for the recognition of both new entrants and exiting firms, as well as the opening and closure of subsidiary establishments. Mobility of workers and business owners across firms and establishments over time can also be traced. For each firm, data are available for size (employment), age, location, sector, and number of establishments. 
Data on business owners and employees include gender, age, function (hierarchical level $),{ }^{6}$ tenure, and formal education.

We focus our analysis on the founders of startups using four sets (or cohorts) of two years each: 1995-96; 1997-98; 1999-2000, and 2001-2002. Estimating econometric models for the four cohorts separately allows us to check the structure of the data and robustness of results. We restrict the size of cohorts to two years since human capital stocks are likely to depreciate, so it is better to compare founders of ventures started within a relatively short period of time. Furthermore, separating cohorts of entrants into two-year periods also avoids business cycle effects which affect firms entering in multiple years differently. Models pooling all data together are also estimated. ${ }^{7}$ We are able to track the background of every founder to the first available year of data, which is 1986. This means that, for the first year (1995) we trace the work history of founders for the period 1986-94, while for the last year (2002) we trace the work history of founders for the period 1986-2001. This way we are able to build substantial information on their past professional, entrepreneurial and industry-specific experience.

The sample includes startups in both services and manufacturing, defined at the three digit level of aggregation. ${ }^{8}$ We deliberately use the founder, and not the firm, as the unit of analysis, choosing not to aggregate measures of entrepreneurial human capital, and instead control for those founders who have partners. ${ }^{9}$ We follow this procedure since aggregating human capital across new business founders is not a simple task. On one

\footnotetext{
${ }^{6}$ The data have information about each individual's occupational position and status within the firm coded using the International Standard Classification of Occupations (ISCO) and the International Classification by Status in Employment (ICSE).

${ }^{7}$ Year-level dummy variables are included in these estimations.

${ }^{8}$ While the data allow for lower levels of industry aggregation, a change in ISIC definitions in 1994 prevents us from making correspondences between sectors before and after that alteration. Such correspondences are indispensable to track founders' pre-entry experiences.

${ }^{9}$ About $51 \%$ of startups are founded by entrepreneurial teams.
} 
hand, it is not clear whether simply adding indicators of entrepreneurial human capital across the entrepreneurial team would produce an accurate measure of entrepreneurial human capital for the firm; on the other hand, considering only one of the founders as representative of the firm (even if it is the one with the highest levels of entrepreneurial human capital) while ignoring the other partners is also likely to be inaccurate.

We expect that firms started by teams of founders will have a greater chance of survival, since a team likely benefits from more entrepreneurial human capital than a single founder. Young businesses are usually formed of like-minded individuals with the same initial view about the best course of action for the firm (Klepper, 2007), so the cohesion of the team will be high, at least in the first years after founding. Often teams coalesce to launch a venture because their members have worked together as employees in a larger organization or in a previous entrepreneurial venture; at other times, the founders themselves select team members, often with diverse talents and skills (Barney et al., 1996), so the process of venture team formation may endow teams with complementary knowledge and capabilities.

$Q P$ data include all wage workers and business owners who are at least 18 years old. While we include all founders in our sample regardless of their year of birth, we control for founder age by including dummy variables for age classes: less than 30 years old; 30-39 years old; and 40-49 years old. The age class that serves as reference for the age dummies corresponds to founders that are 50 years or older). ${ }^{10}$ While older people have had more time to build better networks, identify valuable opportunities, and are more likely to have accumulated capital to finance the startup (Blanchflower and Oswald,

\footnotetext{
10 Entrepreneur age is measured in the year of founding. Using dummy variables for age classes considerably reduces the inevitable high correlation between age and work experience.
} 
1998), evidence shows that the positive effect of age on the probability of success fades as age increases, since older people may be less prone to embark upon the more demanding work schedules required by self-employment, and are closer to retirement (Evans and Leighton, 1989). We group all founders who are 50 years or older into a single age class since several empirical studies suggest that the negative effect of age on survival starts to dominate the positive effect around this age (Rees and Shah, 1986; Carrasco, 1999).

Table 1 displays the main descriptive statistics for each cohort of founders as well as the total sample. The number of startups recorded increased consistently during the period of analysis. This could be partly due to increased coverage of the database. However, since all the firms report their age and the tenure of their employees, it is possible to identify true startups vs. firms that simply show up in the database for the first time. Hence, our sample reflects a true increase in startup activity.

\section{Table 1 about here}

The average age of founders, the number of founders per firm, the proportion of unemployed founders and the proportion of survivors show little variation across the four cohorts. The proportion of previously unemployed ${ }^{11}$ founders is particularly striking, at over $75 \%$ for the whole sample, never falling below $72 \%$ for any of the cohorts.

\footnotetext{
${ }^{11}$ The average length of an unemployment spell in our data is 1.3 years. While the vast majority of individuals who appear 'unemployed' in the Quadros de Pessoal database in fact correspond to the share of the workforce who is without occupation and actively searching for employment, a small minority may be composed of inactive individuals (e.g. people who were once employed but went back to being full time students), or individuals who are employed in industries not covered by the database (e.g. agriculture).
} 
Tables 1A and 1B present separate descriptive statistics for previously unemployed (necessity-based) and previously employed (opportunity-based) founders. The proportion of opportunity-based founders increases from about $22 \%$ in $1995-96$ to about $27 \%$ in 2001-2002. Key statistics appear not to be much different for the two types of founders: they are, on average, about the same age, start similarly sized companies (slightly larger for opportunity-based entrepreneurs) ${ }^{12}$ and form similarly sized venture teams. The survival rate of opportunity-driven founders is a little above average in all cohorts and for the whole sample, while the survival rate for unemployment-driven founders is consistently slightly below average.

\section{Tables $1 \mathrm{~A}$ and $1 \mathrm{~B}$ about here}

Detailed variable definitions plus descriptive statistics for the whole sample (19952002) are presented in Table 2. Spinouts represent about $7 \%$ of the sample, while portfolio entrepreneurs are about $6 \%$.

\section{Table 2 about here}

Table 3 presents the correlation matrix. Correlations between explanatory variables are generally small, with the exception of work experience and industry-specific experience, which are highly positively correlated (correlation coefficient of 0.62 ); however, this correlation does not seem to affect the estimations significantly.

\section{Table 3 about here}

\footnotetext{
${ }^{12}$ During the period under analysis, there was no government support specifically directed at start-ups by the unemployed in Portugal. Support was available equally regardless of employment status.
} 
Assuming that necessity-based entrepreneurship corresponds directly to unemployment-driven entrepreneurship raises some problems, since data are collected on a yearly basis. Firstly, a founder of a new business in year $t$ who was registered as unemployed in year $t-1$ might have found a job in between the data collection time in year $t-1$ and the new business start. Someone in these circumstances is recorded by the data as if he/she were starting the firm following unemployment, when in fact he/she is starting the firm following employment. Likewise, a founder of a new business in year $t$ who was registered as employed at time $t-1$ might have undergone a short spell of unemployment in between the data collection time in year $t-1$ and the new business start, and is therefore erroneously recorded by the data as if he/she were starting the firm following employment. In spite of such limitations, we believe the approach followed here to be advantageous for the study of the research questions investigated in the present paper.

\subsection{Methodology}

We observe firms in the year of entry and again three years later. Our dependent variable (survival) is a dummy that assumes value one if the firm is still operating and the founder is still the owner (or one of the owners) three years after startup, and value zero otherwise. Exit may result from closure or acquisition. However, acquisition is a rare phenomenon in the Portuguese context (Mata et al., 1995) and the overwhelming majority of exits is likely to result from closure.

All variables used refer to the moment of entry, as we are interested in the effect of founding conditions (such as the pre-entry experiences of entrepreneurs) on early survival. The effect of the explanatory variables can then be captured using the Logit 
regression model of the probability of survival. In order to examine the differences in outcomes between opportunity-driven and unemployment-driven entrepreneurs, we estimate separate models for those founders who were previously employed and for those who were previously unemployed. In this way we are able to verify whether the effects of the entrepreneur human capital variables differ according to the type of entrepreneur. $^{13}$

\section{Results}

Logit models for the probability of survival three years after startup are estimated for each cohort separately and for the whole sample. In all estimations the standard errors are clustered at the firm level. The results are, in general, quite comparable, confirming that the models are robust and each of the cohorts displays similar features. Table 4 presents the estimations for a 'reduced' model including both opportunity-based and unemployment-driven founders using only firm-level variables and industry dummies (the controls), and a dummy variable identifying previously employed founders. Coefficients for the estimations using the whole sample are, in general, more significant than coefficients for estimations using each individual cohort, which should be expected given the larger number of observations. The signs of the coefficients for each variable are persistently the same across cohorts and for the whole sample.

\section{Table 4 about here}

\footnotetext{
13 An alternative procedure would be to estimate single models including interaction (moderator) variables corresponding to the product between the employment (opportunity-based) dummy and each of the entrepreneur human capital variables. However, the estimation of separate models for each type of entrepreneur avoids using interaction effects whose interpretation, especially in a Logit framework, is always problematic.
} 
Of particular interest are the coefficients for the Employment variable in Table 4. The expectation is that previously employed (i.e. opportunity-based) founders should be significantly more likely to survive than unemployment-driven ones, but the positive coefficients are only weakly significant for the whole sample and two of the cohorts. Hence, hypothesis $H 1$ is supported only weakly by the data, if at all. This result suggests that differences between opportunity-based and unemployment-driven founders do not necessarily arise directly from the nature or quality of the opportunity being exploited, and are more likely to result from the use of their abilities (i.e. accumulated human capital).

In Tables 5A and 5B we estimate separate models for previously unemployed and previously employed founders, adding the entrepreneurial human capital variables to the mix of explanatory variables in order to test hypothesis $H 2 .{ }^{14}$ The inclusion of the set of variables accounting for entrepreneurial characteristics in Tables $5 \mathrm{~A}$ and $5 \mathrm{~B}$ significantly improves the models. ${ }^{15}$ A model testing the effects of different sources or forms of entrepreneur human capital for the sample as a whole was also estimated, ${ }^{16}$ showing mixed results for the effects of human capital variables. Portfolio entrepreneurs and spinout founders are significantly more likely to survive, confirming our expectations for these two types of entrepreneurial human capital, while other entrepreneurial human capital variables are insignificant. These results suggest that advantages of entrepreneurs who were not unemployed before startup concentrate on

\footnotetext{
${ }^{14}$ A model pooling all entrepreneurs and adding interaction effects between the Employment variable and the human capital variables was estimated, showing significantly positive interaction effects favoring previously employed founders, thus supporting the results of the separate estimations presented here. Results are available from the authors upon request.

15 Tests comparing the Wald statistics for models with and without the variables accounting for entrepreneurial characteristics show that the inclusion of this set of variables significantly improves explanatory power at the $1 \%$ significance level for all cohorts individually and the sample as a whole.

${ }^{16}$ Results are omitted due to lack of space and are available from the authors upon request.
} 
spinout founders and portfolio entrepreneurs, while there seem to be no significant differences in early survival probabilities between unemployment-driven entrepreneurs and previously employed entrepreneurs who are not part of those two specific groups.

\section{Tables 5A, 5B about here}

The effects of both firm-level variables and industry dummies are analogous for both types of founders, suggesting that any differences in performance are likely to originate from entrepreneurial characteristics (human capital). The control variables have, in general, the expected effects, confirming previous findings in the empirical literature. The variable accounting for employee education becomes insignificant when entrepreneur human capital variables are added, which is not surprising since startups are usually small (the average startup size across all cohorts is 4.34 wage earners) and their faith is more likely to hinge on the founders' choices. ${ }^{17}$ Entrepreneurial teams are significantly more likely to survive the critical first years after startup, suggesting that there are tangible and intangible features of entrepreneurial human capital that can be added or matched across the members of the entrepreneurial team, positively influencing startup survival.

The estimations in Table 5B do not include the variables accounting for spinouts and portfolio entrepreneurs, since in these cases the founders were not unemployed before startup. Comparing effects of the other sources of entrepreneurial human capital between opportunity-based and unemployment-driven entrepreneurs provides quite striking results. While the variables accounting for age, gender, and the existence of an entrepreneurial team yield consistent results, the coefficient estimations for

\footnotetext{
${ }^{17}$ Also, recent research finds evidence of a match between founders' and early employees' characteristics and human capital (Baptista et al., 2013).
} 
entrepreneurial human capital variables yield very different results for necessitybased/unemployment-driven (Table 5A) and opportunity-based (Table 5B) founders.

While variables accounting for education levels and specific forms of human capital are generally insignificant (and even display counter-intuitive signs, as is the case of industry experience and managerial experience) for necessity-based/unemploymentdriven entrepreneurs, the same variables are significant and display the expected signs for opportunity-based entrepreneurs. We can therefore claim that our hypothesis $H 2$ is in general supported by the data.

Higher levels of education have a significantly positive impact on the probability of early survival for both types of founders. ${ }^{18}$ However, work experience, industry experience, and managerial experience only contribute significantly to increase the probability of early survival of opportunity-based entrepreneurs (across all cohorts and for the whole sample) and not for necessity-based ones.

Entrepreneurial experience seems to be an important factor in the survival of necessity-based entrepreneurs, but not of opportunity-based ones. This suggests that, in the case of opportunity-based founders, other kinds of pre-entry human capital such as general education and work, industry, and managerial experience can successfully compensate for the lack of entrepreneurial experience in the case of opportunity-driven entrepreneurs, possibly because higher levels of general and specific human capital help founders learn faster about the market, technology, and internal organization, and

\footnotetext{
${ }^{18}$ The completion of a high school degree seems to have a bigger impact when compared with primary education than a university degree, but both are significantly positive across all cohorts and for the complete sample.
} 
provide them with the required networks of contacts regarding sources of finance, prospective customers, and suppliers.

Overall, the results suggest that, while a variety of forms of specific human capital (particularly industry-specific and managerial experience) counterbalance the lack of entrepreneurial experience in opportunity-driven founders, unemployment-driven founders may benefit from accumulated learning that occurred in previous entrepreneurial experiences which might provide them with knowledge about how to sustain a business in the early years, or possibly make them more persistent in the face of poor outcomes.

\section{Concluding Remarks}

This study sought to examine the role played by pre-entry capabilities and human capital associated with the experiences of founders in contributing for the early survival of new businesses, highlighting differences between opportunity based and necessitybased/unemployment-driven entrepreneurs. It can be argued that entrepreneurial characteristics play an especially important role in the critical early years of a startup, when the mission and organization of the firm are being established, and the hiring of key personnel is being carried out.

In summary, the results imply that for entrepreneurs who were employed prior to startup - that is, those more likely to be driven by opportunity discovery - both general and specific forms of entrepreneurial human capital contribute to increase the probability of surviving the critical first three years after startup. However, for 
entrepreneurs who were unemployed prior to startup - and therefore more likely to be starting a firm as an escape from unemployment - only previous entrepreneurial experience seems to increase significantly the probability of early survival. The results also highlight two cases where the chances of early survival are especially strong and significant: spinout founders and portfolio entrepreneurs have consistently greater chances of early survival than other founders.

The creation of new firms involves both opportunity discovery and evaluation, as would-be entrepreneurs decide whether an opportunity can be turned into a business which is sufficiently profitable to offset the opportunity costs involved. Opportunity evaluation and exploitation involves knowledge about demand, technology, organization, customers and suppliers that may be learned by founders prior to entry. The advantages uncovered for spinout founders and portfolio entrepreneurs, as well as the findings that industry-specific and managerial experience matter only for founders who were not unemployed prior to startup, suggest that these are indeed more likely to have engaged in opportunity evaluation and are better equipped for opportunity exploitation, while unemployment-driven entrepreneurs are less likely to search and evaluate opportunities, relying on previous entrepreneurial experience to persevere in the early years after startup.

The specific phenomena of spinouts and portfolio entrepreneurship deserve particular attention in the study of pre-entry capabilities and entrepreneurial human capital. Firstly, spinouts probably incorporate an organizational heritage from the parentcompany, by which founders possibly replicate knowledge, technologies and organizational features learned in the firms they left, which represent the environments 
where they probably discovered their entrepreneurial opportunity (Klepper, 2001; 2007); secondly, portfolio entrepreneurship is likely to provide more network connections and knowledge of potential customers, and a greater ability to overcome financial constraints. In particular, it is likely that for both types of founders the opportunity for the new business was discovered and evaluated in the environment of the previous business.

We believe these results hold meaningful implications for both theory building and policy-making. Pre-entry knowledge of entrepreneurs is a significant determinant of early survival, but mostly in the cases where founders actually bore an opportunity cost (leaving their previous employment) to pursue an entrepreneurial opportunity. In these cases, pre-entry knowledge associated with general and specific human capital helps discover and evaluate opportunities, set up the business, and endure the critical first years after founding, possibly by facilitating more cumulative learning about the market. It can be argued that these entrepreneurs are the ones more likely to grow their businesses, create jobs, and contribute to general economic growth. These results are important for those in charge of private and public institutions dedicated to assist the development of entrepreneurial startups. While aiding startups by the unemployed may be a socially important endeavor, policy makes should not expected these startups to survive in the long term and contribute significantly to employment growth. In contrast, aiding those founders who face an opportunity cost to found their businesses is more likely to provide positive results. 


\section{References}

Acs ZJ, Arenius P, Hay M, Minniti M. (Eds.) 2005. Global Entrepreneurship Monitor2004 Summary Report. Babson College \& London Business School.

Agarwal R, Echambadi R, Franco AM, Sarkar MB. 2004. Knowledge Transfer through Inheritance: Spinout Generation, Development, and Survival. Academy of Management Journal 47:501-522.

Albrecht JW, Edin P, Sundström M, Vroman SB. 1999. Career interruptions and subsequent earnings: a reexamination using Swedish data. Journal of Human Resources 34: 294-311.

Alvarez SA, Busenitz LW. 2001. The Entrepreneurship of Resource-based Theory. Journal of Management 27: 755-775.

Amaral AM, Baptista R, Lima F. 2011. Serial Entrepreneurship: the impact of human capital on time to re-entry. Small Business Economics, 37(1): 1-21.

Andersson P, Wadensjö E. 2006. Do the Unemployed Become Successful Entrepreneurs? A Comparison between the Unemployed, Inactive and WageEarners. International Journal of Manpower, 28(7): 604-626.

Barnett WP, Swanson A-N, Sorenson O. 2003. Asymmetric selection among organizations. Industrial and Corporate Change, 12: 673-695.

Baptista R, Lima F, Preto MT. 2013. Entrepreneurial Skills and Workers' Wages in Small Firms. Small Business Economics 40: 309-323.

Barney J, Busenitz LW, Fiet JO, and Moesel DD. 1996. New venture teams' assessment of learning assistance from venture capital firms. Journal of Business Venturing, 11: $257-272$.

Blanchflower D, Oswald A. 1998. What Makes an Entrepreneur? Journal of Labor Economics 16: 26-60.

Bosma N, van Praag M, Thurik R, de Wit G. 2004. The Value of Human and Social Capital Investments for the Business Performance of Startups. Small Business Economics 23: 227-236.

Brüderl J, Preisendörfer P, Ziegler R. 1992. Survival Chances of Newly Founded Organizations. American Sociological Review 57: 227-242.

Busenitz LG, Page West III G, Shepherd D, Nelson T, Chandler GN, Zacharakis A. 2003. Entrepreneurship Research in Emergence: Past Trends and Future Directions. Journal of Management 29(3): 285-308.

Carrasco R. 1999. Transitions to and from Self-employment in Spain. Oxford Bulletin of Economics and Statistics 61: 315-41.

Colombo M, Delmastro M, Grilli L. 2004. Entrepreneurs' human capital and the startup size of new technology-based firms. International Journal of Industrial Organization 22: 1183-1211.

Conner KR, Prahalad, CK. 1996. A Resource Based Theory of the Firm: Knowledge versus Opportunism. Organization Science 7(5): 477-501. 
Cooper AC, Gimeno-Gascon FJ, Woo CY. 1994. Initial Human and Financial Capital as Predictors of New Venture Performance. Journal of Business Venturing 9: 371395.

Dahl M, Reichstein T. 2007. Are You Experienced? Prior Experience and the Survival of New Organizations. Industry and Innovation 14(5): 497-511.

Eisenhardt KM, Martin JA. 2000. Dynamic Capabilities: What Are They? Strategic Management Journal 21: 1105-1121.

Evans LB, Leighton LS. 1989. Some Empirical Aspects of Entrepreneurship. American Economic Review, 79: 519-535.

Freeman J, Carroll G, Hannan M. 1983. The Liability of Newness - Age Dependence in Organizational Death Rates. American Sociological Review 48: 692-710.

Geroski PA. 1995. What Do We Know About Entry? International Journal of Industrial Organization 13: 421- 440.

Gerosky PA, Mata J, Portugal P. 2010. Founding Conditions and the Survival of New Firms. Strategic Management Journal 31: 510-529.

Grant R. 1996. Toward a knowledge-based theory of the firm. Strategic Management Journal 17: 109-122.

Helfat CE, Lieberman MB. 2002. The Birth of Capabilities: Market Entry and the Importance of Pre-history. Industrial and Corporate Change 11: 725-760.

Jovanovic B. 1982. Selection and Evolution of Industry. Econometrica 50: 649-670.

Klepper S. 2001. Employee Startups in High-Tech Industries. Industrial and Corporate Change 10: 639-674.

Klepper S. 2007. Disagreements, Spinoffs, and the Evolution of Detroit as the Capital of the U.S. Automobile Industry. Management Science 53: 616-631.

Littunen H, Streamer E, Nenonen T. 1998. Survival of Firms over the Critical First Three Years and The Local Environment. Entrepreneurship \& Regional Development 10: 189-202.

Mata J, Portugal P. 2002. The Survival of New Domestic and Foreign-Owned Firms. Strategic Management Journal 23: 323-343.

Mata J, Portugal P, Guimarães P. 1995. The Survival of New plants: Entry Conditions and Post-entry Evolution. International Journal of Industrial Organization 13: 459-482.

McGrath RG, Macmillan I. 2000. The Entrepreneurial Mindset. Harvard Business School Press: Boston, MA.

Mincer J, Ofek H. 1982. Interrupted Work Careers: Depreciation and Restoration of Human Capital. Journal of Human Resources 17(1): 3-24.

Neuman S, Weiss A. 1995. On the Effects of Schooling Vintage on Experience-earnings Profiles: Theory and Evidence. European Economic Review 39: 943-955. 
Parker SC. 2013. Do Serial Entrepreneurs Run Successively Better-performing Businesses? Journal of Business Venturing 28(5):652-666

Peteraf MA. 1993. The Cornerstones of Competitive Advantage: a Resource-based View. Strategic Management Journal 14: 179-191.

Pfeiffer F, Reize F. 2000. Business Startups by the Unemployed - An Econometric Analysis Based on Firm Data. Labour Economics 7: 629-63.

Quatraro F, Vivarelli M. 2013. Drivers of Entrepreneurship and Post-Entry Performance of Newborn Firms in Developing Countries. IZA Discussion Paper \#7436.

Rees H, Shah A. 1986. An Empirical Analysis of Self-employment in the U.K. Journal of Applied Econometrics 1: 101-108.

Santarelli E, Vivarelli M. 2007. Entrepreneurship and the Process of Firms' Entry, Survival and Growth. Industrial and Corporate Change 16: 455-488.

Shane S. 2000. Prior Knowledge and the Discovery of Entrepreneurial Opportunities. Organization Science 11: 448-469.

Shane S, Venkataraman S. 2000. The Promise of Entrepreneurship as a Field of Research. Academy of Management Review 25: 217-226.

Sluis JV, Praag, MV, Vijverberg W. 2005. Entrepreneurship, Selection and Performance: A Meta-analysis of the Impact of Education in Less Developed Countries. World Bank Economic Review 19: 225-261

Stam E, Audretsch DB, Meijaard. 2008. Renascent entrepreneurship. Journal of Evolutionary Economics 18: 493-507.

Stam E, Thurik R, van der Zwan P. 2010. Entrepreneurial exit in real and imagined markets. Industrial and Corporate Change 19: 1109-1139.

Storey DJ. 1991. The Birth of New Firms - Does Unemployment Matter? A Review of the Evidence. Small Business Economics 3: 167-78.

Storey DJ, Jones AM. 1987. New Firm Formation - A Labor Market Approach to Industrial Entry. Scottish Journal of Political Economy 34: 37-51.

Ucbasaran D, Wright M, Westhead P. 2003. A Longitudinal Study of Habitual Entrepreneurs: Starters and Acquirers. Entrepreneurship \& Regional Development 15: 207-228.

Teece, DJ, Pisano G, Shuen A. 1997. Dynamic Capabilities and Strategic Management. Strategic Management Journal 18:509-533.

Ucbasaran D, Wright M, Westhead P. 2008. Opportunity identification and pursuit does an entrepreneur's human capital matter? Small Business Economics 30: 153-173.

Vivarelli M. 2007. Entry and Post-Entry Performance of Newborn Firms. London: Routledge. 
Table 1: Descriptive statistics for the four cohorts of founders

\begin{tabular}{|l|r|r|r|r|r|r|}
\hline Cohorts & $\begin{array}{c}\text { No. of } \\
\text { Founders }\end{array}$ & $\begin{array}{c}\text { Avg. } \\
\text { Startup } \\
\text { Size }\end{array}$ & $\begin{array}{c}\text { Avg. } \\
\text { Age of } \\
\text { Founder }\end{array}$ & $\begin{array}{c}\text { No. of } \\
\text { Founders } \\
\text { per Firm }\end{array}$ & $\begin{array}{c}\text { Percentage of } \\
\text { Unemployed } \\
\text { Founders }\end{array}$ & $\begin{array}{c}\text { Percentage of } \\
\text { Founders } \\
\text { Surviving after } \\
\text { three years }\end{array}$ \\
\hline $\mathbf{1 9 9 5 - 1 9 9 6}$ & 28772 & 4.70 & 36.28 & 1.38 & 77.38 & 74.69 \\
\hline $\mathbf{1 9 9 7 - 1 9 9 8}$ & 32180 & 4.57 & 36.15 & 1.37 & 78.51 & 75.99 \\
\hline $\mathbf{1 9 9 9 - 2 0 0 0}$ & 44749 & 3.95 & 35.88 & 1.37 & 77.68 & 72.50 \\
\hline $\mathbf{2 0 0 1 - 2 0 0 2}$ & 64217 & 4.32 & 38.72 & 1.39 & 72.02 & 79.07 \\
\hline Total & 169918 & 4.34 & 37.07 & 1.38 & 75.65 & 76.01 \\
\hline
\end{tabular}

Table 1A: Descriptive statistics for the four cohorts of previously unemployed founders

\begin{tabular}{|l|r|r|r|r|r|}
\hline Cohorts & $\begin{array}{c}\text { No. of } \\
\text { Founders }\end{array}$ & $\begin{array}{c}\text { Avg. } \\
\text { Startup } \\
\text { Size }\end{array}$ & $\begin{array}{c}\text { Avg. Age of } \\
\text { Founder }\end{array}$ & $\begin{array}{c}\text { No. of } \\
\text { Founders } \\
\text { per Firm }\end{array}$ & $\begin{array}{c}\text { Percentage of } \\
\text { Founders Surviving } \\
\text { after three years }\end{array}$ \\
\hline $\mathbf{1 9 9 5 - 1 9 9 6}$ & 22263 & 4.37 & 36.13 & 1.36 & 74.38 \\
\hline $\mathbf{1 9 9 7 - 1 9 9 8}$ & 25266 & 4.23 & 35.97 & 1.36 & 75.49 \\
\hline $\mathbf{1 9 9 9 - 2 0 0 0}$ & 34759 & 3.61 & 35.93 & 1.36 & 71.86 \\
\hline $\mathbf{2 0 0 1 - 2 0 0 2}$ & 46248 & 4.10 & 39.07 & 1.37 & 78.09 \\
\hline Total & 128536 & 4.04 & 37.10 & 1.36 & 75.25 \\
\hline
\end{tabular}

Table 1B: Descriptive statistics for the four cohorts of previously employed founders

\begin{tabular}{|l|r|r|r|r|r|}
\hline Cohorts & $\begin{array}{c}\text { No. of } \\
\text { Founders }\end{array}$ & $\begin{array}{c}\text { Avg. } \\
\text { Startup } \\
\text { Size }\end{array}$ & $\begin{array}{c}\text { Avg. Age of } \\
\text { Founder }\end{array}$ & $\begin{array}{c}\text { No. of } \\
\text { Founders } \\
\text { per Firm }\end{array}$ & $\begin{array}{c}\text { Percentage of } \\
\text { Founders Surviving } \\
\text { after three years }\end{array}$ \\
\hline $\mathbf{1 9 9 5 - 1 9 9 6}$ & 6509 & 6.01 & 36.80 & 1.43 & 75.74 \\
\hline $\mathbf{1 9 9 7 - 1 9 9 8}$ & 6914 & 6.04 & 36.79 & 1.41 & 77.80 \\
\hline $\mathbf{1 9 9 9 - 2 0 0 0}$ & 9990 & 5.29 & 35.67 & 1.40 & 74.72 \\
\hline $\mathbf{2 0 0 1 - 2 0 0 2}$ & 17969 & 4.98 & 37.83 & 1.45 & 81.57 \\
\hline Total & 41382 & 5.39 & 36.97 & 1.43 & 78.37 \\
\hline
\end{tabular}


Table 2: Variable definitions and descriptive statistics

\begin{tabular}{|c|c|c|c|c|c|c|}
\hline Variable & Definition & $\begin{array}{l}\text { No. } \\
\text { Obs* }\end{array}$ & Mean & $\begin{array}{l}\text { Std. } \\
\text { Dev. }\end{array}$ & Min & Max \\
\hline Survival & $\begin{array}{l}\text { Variable }=1 \text { if both firm and founder remain active } \\
\text { three years after founding, and } 0 \text { otherwise }\end{array}$ & 169918 & 0.76 & 0.43 & 0 & 1 \\
\hline Log Size & $\begin{array}{l}\text { Log of the number of employees of the firm at } \\
\text { founding }\end{array}$ & 169918 & 1.23 & 0.73 & 0 & 6.46 \\
\hline Emp Education & $\begin{array}{l}\text { Proportion of employees that are university } \\
\text { graduates at founding }\end{array}$ & 165354 & 0.016 & 0.11 & 0 & 1 \\
\hline Age below 30 & $\begin{array}{l}\text { Variable }=1 \text { if founder is } 29 \text { years of age or } \\
\text { younger at the time of founding, and } 0 \text { otherwise }\end{array}$ & 161582 & 0.20 & 0.40 & 0 & 1 \\
\hline Age 30-39 & $\begin{array}{l}\text { Variable }=1 \text { if founder is between } 30 \text { and } 39 \text { years } \\
\text { of age at the time of founding, and } 0 \text { otherwise }\end{array}$ & 161582 & 0.36 & 0.48 & 0 & 1 \\
\hline Age 40-49 & $\begin{array}{l}\text { Variable }=1 \text { if founder is between } 40 \text { and } 49 \text { years } \\
\text { of age at the time of founding, and } 0 \text { otherwise }\end{array}$ & 161582 & 0.27 & 0.44 & 0 & 1 \\
\hline Gender & Variable $=1$ if founder is female, and 0 if it is male & 169918 & 0.28 & 0.45 & 0 & 1 \\
\hline University Grad & $\begin{array}{l}\text { Variable }=1 \text { if founder is a university graduate at } \\
\text { the time of founding, and } 0 \text { otherwise }\end{array}$ & 167838 & 0.08 & 0.28 & 0 & 1 \\
\hline $\begin{array}{l}\text { High School } \\
\text { Grad }\end{array}$ & $\begin{array}{l}\text { Variable }=1 \text { if founder is a high school graduate at } \\
\text { the time of founding, and } 0 \text { otherwise }\end{array}$ & 167838 & 0.17 & 0.38 & 0 & 1 \\
\hline Work Exp & $\begin{array}{l}\text { Number of years since founder entered the labor } \\
\text { market }\end{array}$ & 169918 & 1.58 & 2.20 & 0 & 8 \\
\hline Spinout & $\begin{array}{l}\text { Variable }=1 \text { if founder was working in an } \\
\text { incumbent of the startup's industry in the year } \\
\text { before founding, and } 0 \text { otherwise }\end{array}$ & 169918 & 0.07 & 0.25 & 0 & 1 \\
\hline Industry Exp & $\begin{array}{l}\text { Number of years founder worked in the startup's } \\
\text { industry prior to founding }\end{array}$ & 169918 & 1.31 & 1.98 & 0 & 8 \\
\hline Managerial Exp & $\begin{array}{l}\text { Number of years the founder worked in one of the } \\
\text { top three hierarchical levels listed in the data set }\end{array}$ & 169918 & 0.52 & 1.28 & 0 & 8 \\
\hline Entrep Exp & $\begin{array}{l}\text { Variable = } 1 \text { if individual has founded at least one } \\
\text { firm in the past, but was not a business owner at } \\
\text { founding, and } 0 \text { otherwise }\end{array}$ & 169918 & 0.16 & 0.37 & 0 & 1 \\
\hline Portfolio & $\begin{array}{l}\text { Variable }=1 \text { if individual owned at least another } \\
\text { business at founding, and } 0 \text { otherwise }\end{array}$ & 167838 & 0.06 & 0.38 & 0 & 1 \\
\hline Entrep Team & $\begin{array}{l}\text { Variable }=1 \text { if firm is being founded by more than } \\
\text { one individual, and } 0 \text { otherwise }\end{array}$ & 169918 & 0.51 & 0.50 & 0 & 1 \\
\hline Employment & $\begin{array}{l}\text { Variable }=1 \text { if founder was employed in the year } \\
\text { before founding }\end{array}$ & 169918 & 0.24 & 0.43 & 0 & 1 \\
\hline Year Dummies & \multicolumn{6}{|c|}{$\begin{array}{l}\text { Year dummies for cohort estimations: Variables }=1 \text { for firms founded in } 1995 \text { and } 0 \\
\text { otherwise; } 1997 \text { and } 0 \text { otherwise; } 1999 \text { and } 0 \text { otherwise; } 2001 \text { and } 0 \text { otherwise }\end{array}$} \\
\hline $\begin{array}{l}\text { Industry } \\
\text { Dummies }\end{array}$ & \multicolumn{6}{|l|}{ Industry dummies at the three-digit level } \\
\hline
\end{tabular}

${ }^{19}$ As pointed out earlier, data report each individual's position in the firm's hierarchy according to a specific code. There are eight categories or hierarchical levels. These are, from lower to higher: apprentices, interns and trainees; non-skilled professionals; semi-skilled professionals; skilled professionals; higher-skilled professionals; supervisors and team leaders; intermediary managers: and top managers. 


\title{
The Impact of Human Capital on the Early Success of Necessity vs. \\ Opportunity-based Entrepreneurs
}

\section{Rui Baptista}

Brunel Business School, Brunel University, UK

and

CEG-IST, Instituto Superior Técnico, University of Lisbon, Portugal

\section{Murat Karaöz}

Department of Econometrics, Faculty of Economics and Administrative Sciences, Akdeniz University, Antalya, Turkey

\section{Joana Mendonça}

IN+ Center for Innovation, Technology and Policy Research, Instituto Superior Técnico, University of Lisbon

\begin{abstract}
This paper examines whether founders' backgrounds influence new firm survival in the early years after startup focusing in particular on the impact of unemploymentdriven entrepreneurship. For entrepreneurs who left their previous employment to found a new firm, both general and specific human capital play a key role in enhancing early survival chances. However, various forms of human capital have little effect on early survival of unemployment-driven entrepreneurs, who rely mostly on previous entrepreneurial experience to persevere. Results suggest that pre-entry capabilities play an important role in the early success of opportunity-based entrepreneurs, but have little influence on the early success of necessity-based ones.
\end{abstract}

Keywords: Entrepreneur Human capital; Pre-entry capabilities; New Firm Survival; Opportunity-based Entrepreneurship; Necessity-based Entrepreneurship. 


\section{Introduction}

Empirical studies of market selection indicate that entrants are heterogeneous and initial conditions influence subsequent success (see, for instance: Geroski et al., 2010). However, most of these studies develop and/or test theories focusing on the fit between firm characteristics and market conditions after those firms have entered markets, and often neglect the role played by the characteristics of founders.

It can be argued that the creation of new firms involves ex-ante selection, as the would-be entrepreneurs evaluate whether an opportunity can be turned into a business which is sufficiently profitable to offset the opportunity costs involved (Barnett et al., 2003; Stam et al., 2010). Two characteristics drive the entry decision: the munificence of opportunities and the availability of resources and capabilities. Research has attempted to develop a structure for theory-building and applied work about the role played by pre-entry resources and capabilities in driving both entry decisions and postentry performance (Helfat and Lieberman, 2002). Prior knowledge enables entrepreneurs to better recognize opportunities (Shane and Venkataraman, 2000) and gives them the ability to exploit them. This knowledge might be unique to entrepreneurs (Alvarez and Busenitz, 2001).

A central argument of this research is that the success of new organizations is fundamentally shaped by the pre-entry experiences of their founders. New organizations benefit from knowledge that was accumulated by their founders throughout their careers (Agarwal et al., 2004). The present paper examines the role played by the backgrounds of founders in influencing new firm survival in the critical early years after startup. In particular, we seek to examine the role played by human capital in influencing the early 
success of individuals who gave up their previous employment position in order to start a business as opposed to those who founded a business following an unemployment spell. It seems logical to expect that the former are significantly more likely to be starting a business in order to exploit a discovered opportunity (opportunity-based entrepreneurs), while the latter are more likely to be starting a business out of necessity (that is, due to the lack of satisfactory employment prospects - necessity-based entrepreneurs).

Research in labor economics has found that interrupted careers translate into depreciation of human capital stocks. We suggest that same might apply to entrepreneurs. Knowledge and skills acquired previously in the labor market are likely to depreciate during interruptions associated with unemployment spells, meaning that entrepreneurs who start firms out of unemployment are not only less likely to have recognized valuable opportunities, but also have less abilities (i.e. specific industry, finance or marketing knowledge, and organizational routines) to exploit them.

Based on the extant literature, we propose hypotheses concerning the contribution of different sources of entrepreneurial human capital ${ }^{1}$ to new firm survival in the early years after startup, and use data on founders' backgrounds to create measures of entrepreneurial human capital arising from these sources in order to test those hypotheses. In particular, we seek to establish whether different sources of entrepreneurial human capital play a different role in driving early survival for opportunity-based (i.e. previously employed) and necessity-based (i.e. previously unemployed) entrepreneurs.

\footnotetext{
${ }^{1}$ We distinguish between a variety of sources of founder human capital: formal education; work experience; industry-specific experience; managerial experience and business ownership experience.
} 
By utilizing a longitudinal database linking firms, founders and employees, our study is able to examine a substantial number of startups and founders in a wide variety of sectors over several years. We contribute to the literature on new firm survival by taking into account the difference between opportunity and necessity (unemployment-driven) entrepreneurs, by using a wide variety of concepts of pre-entry human capital, and also by focusing on the early years in the life of firms.

This research has important implications for both practitioners and policy-makers. Founders play a fundamental role in determining the mission, strategy and organizational structure of new firms, ${ }^{2}$ so studies of new firm success - particularly in the first few years after startup - are fundamentally incomplete when founders' characteristics are overlooked. By looking at the chances of survival in the crucial early years after startup, this study provides insights for policy-makers on where to target government support to struggling young firms in order to maximize their contribution to overall competitiveness and employment.

The rest of the paper is organized as follows. The first part of section 2 reviews the literature establishing the influence of pre-entry capabilities and entrepreneurial human capital on the early success of new businesses and discusses a variety of ways in which entrepreneurs may accumulate specific human capital. In particular, we pay attention to differences between opportunity-based and unemployment-driven entrepreneurs, leading to the development of hypotheses with regard to their effect on new business survival. The second part of section 2 establishes the rationale for firm-level and industry controls. Section 3 presents the data and empirical strategy, while section 4

\footnotetext{
${ }^{2}$ Busenitz et al. (2003, p. 298) point out that "opportunities do not come to fruition without unique insights, perspectives, and interpretations by the founders, and are not transformed into wealth generation without organizing actions."
} 
displays and discusses the estimation results. Finally, section 5 offers some concluding remarks.

\section{Entrepreneurial Human Capital and Factors Influencing Firm Survival}

\subsection{Entrepreneurs' Backgrounds, Human Capital, and Survival}

The early years after startup are crucial for a firm's future. Virtually all studies in economics, management and organizational ecology find that younger firms confront higher probabilities of exit than their older counterparts (see, for instance, Santarelli and Vivarelli, 2007). The entrepreneurship literature often regards the first three years after startup as critical for the survival and success of new firms (Littunen et al., 1998). The Global Entrepreneurship Monitor (GEM) surveys of entrepreneurial activity define young businesses as firms that have been active for three and a half years or less. ${ }^{3}$ Geroski (1995, p. 424), points out that the "mechanism of displacement, which seems to be the most palpable consequence of entry, affects young, new firms more severely." In economics, market selection theories argue that firms are unsure about their efficiency prior to entry and learn from noisy signals provided by the market, leading to higher exit rates for recent startups firms than for older businesses (see, for instance, Jovanovic, 1982). Organizational ecologists speak of 'liability of newness' (Freeman et al., 1983) to describe the stylized fact that hazard rates decline monotonically with age as firms learn and adapt. Newly formed firms are less likely to be able to cope with environmental challenges than established organizations.

\footnotetext{
${ }^{3}$ According to the GEM definition, an enterprise is classified as a young business if it has paid salaries and wages for more than three months but for less than 42 months, and as an established business if it has paid salaries and wages for more than 42 months (Acs et al., 2005).
} 
The findings of economists and organizational ecologists suggest that the faster a firm learns about the fit between its resources and capabilities and market conditions, and the more able it is to adapt its competences to market requirements, the more likely it will survive the critical early years after startup. The availability of pre-entry knowledge about innovative capabilities, marketing and finance, and organizational routines should influence significantly the probability of survival in these critical early years, when firms have had little or no time to learn about the market. For new firms that do not result from diversification or joint venturing operations, pre-entry capabilities are associated primarily with the founders. Entrepreneurs with greater stocks of human capital will be less uncertain about their efficiency and will be able to learn faster about market conditions, therefore reducing the probability of early exit.

Brüderl et al. (1992) propose a framework distinguishing general and specific forms of entrepreneurial human capital, where general human capital includes education levels while specific human capital includes work experience and industry-specific experience. General and specific entrepreneurial human capital enhance the productivity of the founder-manager. We build on this distinction between general and specific forms of entrepreneurial human capital, associating them with specific phenomena that have been highlighted by entrepreneurship research (see, for instance, Dahl and Reichstein, 2007) as being related with the extent of opportunity identification and exploitation: spinouts, habitual entrepreneurship and, in particular, necessity-based vs. opportunity-based entrepreneurship.

Let us start with general human capital. It can be claimed that, through formal education, individuals acquire fundamental abilities to learn about markets and 
technology, and better recognize opportunities in the surrounding environment (Shane, 2000). Formal education also allows individuals to develop learning aptitudes and organizational skills to better organize to exploit those opportunities (Grant, 1996). Consequently, higher levels of education may give the entrepreneur higher ability to solve problems and make decisions regarding business development. Better educated entrepreneurs may also have better social networks, as a result of their longer stay in the education system, and that may be useful for the development of their businesses (Ucbasaran et al., 2008). Furthermore, better educated people should command higher average earnings as paid employees and, therefore, find it easier to fund their new business. In a comprehensive meta-analysis of studies of the returns to education for entrepreneurs, Van der Sluis et al. (2005) conclude that entrepreneurship performance, regardless of the performance measure used, is significantly and positively affected by formal education. We then expect that startups whose founder has a higher level of formal education have a greater probability of early survival.

People with more work experience and who have performed managerial duties are more likely to be in a better position to detect opportunities and raise capital, thus setting up larger and better-equipped businesses (Colombo et al., 2004). Knowledge of how to manage a business has a strong tacit form and can be gained informally by observing and making business decisions (Cooper et al., 1994). People with greater managerial experience are also more likely to have developed the necessary skills to organize new businesses (Shane, 2000). We therefore expect that startups whose founder has more years of work experience and, in particular, more years of managerial experience have a greater probability of early survival. 
Work experience is likely to be more useful for entrepreneurs when it takes place in the industry where the new firm is being started. In particular, entrepreneurs who forfeit employment in an established incumbent to create a startup in the same industry thereby creating a spinout ${ }^{4}$ - are more likely to achieve early success. People who have worked in the same industry for some time are likely to have accrued industry-specific human capital, meaning specialized market and technological knowledge, plus a network of professional and social contacts that facilitate the acquisition and management of both technical and human resources. In addition, people that have worked in the industry may have already established relationships with customers, suppliers, or other stakeholders. Founders with greater industry experience are likely to bring to their new firm specific knowledge about a wide range of issues, such as customer demand, products, technologies, suppliers and competitors (Helfat and Lieberman, 2002). Previous research has shown that experience of the business owner in the same industry in which a new business is started improves a firm's chances of survival and posterior firm performance (Bosma et al., 2004), even if such experience does not occur right before creating a startup. A period of time spent away from the industry may accelerate the depreciation of industry-specific human capital. Hence, while we expect that startups whose founder has more years of experience in the same industry should have a greater probability of early survival, startups whose founder was employed in the same industry right before startup (i.e. spinouts) will benefit more from industry-specific human capital.

\footnotetext{
${ }^{4}$ This definition of spinout is used by, among others, Agarwal et al (2004) and Klepper (2001, 2007) who uses the term "spinoff." While it may be deemed too inclusive (not all founders incorporated into this concept are necessarily exploiting opportunities discovered while working for their previous employer), any bias that may be introduced would counteract the effects supporting the hypotheses being tested.
} 
Specific human capital which is valuable for new business founders also manifests itself through entrepreneurial experience. Habitual entrepreneurs, meaning individuals who have started at least one business prior to founding a new one, ${ }^{5}$ include individuals who own several businesses simultaneously (portfolio entrepreneurs), as well as those who start a business subsequent to closing - or selling - another (serial entrepreneurs). Individuals who have accrued experience as business owners should possess higher accumulated levels of entrepreneurial human capital (Ucbasaran et al., 2003; Stam et al., 2008). In particular, they should have better managerial and technical skills, better networks of contacts, access to market-specific information and knowledge, and thus should be better equipped to discover and take advantage from new business opportunities (McGrath and MacMillan, 2000).

The value of human capital is likely to be different for serial and portfolio entrepreneurs. Serial entrepreneurs experience a break in between entrepreneurial events, which may last for an extended time (Amaral et al., 2011) and is likely to facilitate depreciation of the stock of specific human capital. Serial entrepreneurship is not necessarily associated with success, as it may result simply from a succession of business starts and closures. Portfolio entrepreneurs are less likely to face financial constraints to start a new firm than serial entrepreneurs, since they can deploy assets from their current firm (or firms) in the new startup. Recent research finds that serial entrepreneurs' performance in one venture enhances their performance in subsequent ventures only temporarily (Parker, 2013). Hence, in addition to a positive effect on survival chances from entrepreneurial experience, we expect that startups whose

\footnotetext{
${ }^{5}$ The present study is restricted to business owners who have started their businesses, therefore excluding those who have acquired or inherited ownership. We believe that, in considering only starters and not acquirers and inheritors, we may better approach the concept of entrepreneurship as understood by the management literature (Busenitz et al., 2003).
} 
founder owns one or more other businesses at the time of founding (portfolio entrepreneurs) have a greater probability of early survival.

The key element in our analysis is the distinction between the role played by human capital for opportunity-driven and unemployment-driven entrepreneurs. People who give up their current employment to start a new business incur an opportunity cost, so they are likely to be doing it due to the discovery of a promising business opportunity. People who are driven from unemployment into starting a business are likely to be doing it in order to make ends meet. Unemployment is a powerful driver of new firm creation. Founding a new firm may be an alternative to uncertain future career prospects or even an "escape from unemployment" (Storey, 1991). The empirical evidence highlighting the role played by job losses in fostering new startups is quite robust (Storey and Jones, 1987). If unemployment is the main incentive for setting up a business, there may not be time to look for good opportunities, make detailed plans, get appropriate funding, and seek advice. Hence, the chances of survival may be affected by selection occurring prior to startup.

Specific human capital and entrepreneurial abilities may erode with unemployment spells. Research in labor economics has found that interrupted careers translate into depreciation of human capital stocks. Mincer and Ofek (1982) established that interrupted work careers entail substantial wage reductions upon re-entry to the labor market, implying depreciation in human capital stocks. A substantial body of subsequent research has confirmed that human capital depreciates with time spent away from the workplace (see, for instance, Neuman and Weiss, 1995; Albrecht et al., 1999). Entrepreneurs' knowledge and skills acquired previously in the labor market (either as a 
business owner or a paid employee), while remaining of some value, gradually become less applicable as circumstances change, and interruptions associated with unemployment spells are likely to accelerate the depreciation of human capital stocks, meaning that entrepreneurs who start firms out of unemployment have less abilities (i.e. specific industry, finance or marketing knowledge, and organizational routines) to exploit them.

Empirical evidence on entrepreneurial careers has found that those who have entered self employment directly from unemployment exit to a higher extent than those who have entered directly from paid employment (Carrasco, 1999; Pfeiffer and Reize, 2000), and that new founders who were formerly unemployed have on average lower economic outcomes and a lower propensity to positively contribute to job creation (Andersson and Wadensjö, 2006). In view of this discussion, we formulate two key hypotheses:

H1: startups whose founder was unemployed right before founding have a lower probability of early survival.

H2: different forms of specific human capital of founders may have less positive impacts on firm survival probabilities for unemployment-driven entrepreneurs than for other entrepreneurs.

\subsection{Control Variables}

Mortality rates vary consistently across firms and industries, regardless of age. An extensive literature examining firm-level and industry-level determinants of new firm survival and growth has built up over the last decades. Comprehensive reviews of such determinants are provided by Santarelli and Vivarelli (2007), and Quatraro and Vivarelli 
(2013). We use the main results from this literature as guidance for the choice of controls used in this study.

The main firm-level determinant of survival is startup size. While the theoretical literature does not point towards a clear prediction of the effect of firm size on survival, empirical evidence supporting a "liability of smallness", meaning a negative relationship between hazard rates and size, is overwhelmingly unambiguous (Vivarelli, 2007). Therefore, we expect that firms that enter at a lower scale will have a lower probability of survival and use firm size at the time of founding as a control variable.

The resource-based view of the firm posits that the ability of firms to survive and to compete successfully is strongly influenced by the extent to which firms develop firmspecific assets, processes and routines which cannot be easily imitated by competitors (Peteraf, 1993; Eisenhardt and Martin, 2000). A number of authors have pointed out that a firm's knowledge resides in its human resources (Conner and Prahalad, 1996; Teece et al., 1997). Mata and Portugal (2002) argue that the level of the formal education held by a firm's workforce can be regarded as a measure, albeit imperfect, of firm-specific resources and capabilities. We therefore use the level of education of employees at the time of founding as a control.

The literature reports four main industry-level features influencing survival: i) economies of scale; ii) market concentration; ii) barriers to entry; and iv) industry growth (see, for instance, Mata and Portugal, 2002; Santarelli and Vivarelli, 2007). However, the effects of some of these factors are not always consistent in the theoretical and empirical literature (Vivarelli, 2007). Since the industry where the startup occurs 
clearly influences survival in a variety of ways, this study accounts for this influence by using industry fixed effects (i.e. industry dummies) in the empirical analysis.

Finally, we also control for the gender of the entrepreneur. Empirical findings on the success of ventures started by female entrepreneurs have been mixed. For instance, Cooper et al. (1994) find that firms with a male entrepreneur have a greater probability of high growth, but not of survival.

\section{Data and Methodology}

\subsection{Data}

We explore the Quadros de Pessoal (QP) database, a longitudinal matched employer-employee data set built from mandatory information submitted annually by all firms with at least one wage earner (excluding agriculture) to the Portuguese Ministry of Employment and Social Security covering the period from 1986 to 2005 . There are a minimum of 145,000 firms, 170,000 establishments and 2,000,000 workers and business owners included in each annual survey. Firms, establishments and individuals are fully cross-referenced through the use of a unique identification number, thus allowing for the recognition of both new entrants and exiting firms, as well as the opening and closure of subsidiary establishments. Mobility of workers and business owners across firms and establishments over time can also be traced. For each firm, data are available for size (employment), age, location, sector, and number of establishments. 
Data on business owners and employees include gender, age, function (hierarchical level $),{ }^{6}$ tenure, and formal education.

We focus our analysis on the founders of startups using four sets (or cohorts) of two years each: 1995-96; 1997-98; 1999-2000, and 2001-2002. Estimating econometric models for the four cohorts separately allows us to check the structure of the data and robustness of results. We restrict the size of cohorts to two years since human capital stocks are likely to depreciate, so it is better to compare founders of ventures started within a relatively short period of time. Furthermore, separating cohorts of entrants into two-year periods also avoids business cycle effects which affect firms entering in multiple years differently. Models pooling all data together are also estimated. ${ }^{7}$ We are able to track the background of every founder to the first available year of data, which is 1986. This means that, for the first year (1995) we trace the work history of founders for the period 1986-94, while for the last year (2002) we trace the work history of founders for the period 1986-2001. This way we are able to build substantial information on their past professional, entrepreneurial and industry-specific experience.

The sample includes startups in both services and manufacturing, defined at the three digit level of aggregation. ${ }^{8}$ We deliberately use the founder, and not the firm, as the unit of analysis, choosing not to aggregate measures of entrepreneurial human capital, and instead control for those founders who have partners. ${ }^{9}$ We follow this procedure since aggregating human capital across new business founders is not a simple task. On one

\footnotetext{
${ }^{6}$ The data have information about each individual's occupational position and status within the firm coded using the International Standard Classification of Occupations (ISCO) and the International Classification by Status in Employment (ICSE).

${ }^{7}$ Year-level dummy variables are included in these estimations.

${ }^{8}$ While the data allow for lower levels of industry aggregation, a change in ISIC definitions in 1994 prevents us from making correspondences between sectors before and after that alteration. Such correspondences are indispensable to track founders' pre-entry experiences.

${ }^{9}$ About $51 \%$ of startups are founded by entrepreneurial teams.
} 
hand, it is not clear whether simply adding indicators of entrepreneurial human capital across the entrepreneurial team would produce an accurate measure of entrepreneurial human capital for the firm; on the other hand, considering only one of the founders as representative of the firm (even if it is the one with the highest levels of entrepreneurial human capital) while ignoring the other partners is also likely to be inaccurate.

We expect that firms started by teams of founders will have a greater chance of survival, since a team likely benefits from more entrepreneurial human capital than a single founder. Young businesses are usually formed of like-minded individuals with the same initial view about the best course of action for the firm (Klepper, 2007), so the cohesion of the team will be high, at least in the first years after founding. Often teams coalesce to launch a venture because their members have worked together as employees in a larger organization or in a previous entrepreneurial venture; at other times, the founders themselves select team members, often with diverse talents and skills (Barney et al., 1996), so the process of venture team formation may endow teams with complementary knowledge and capabilities.

$Q P$ data include all wage workers and business owners who are at least 18 years old. While we include all founders in our sample regardless of their year of birth, we control for founder age by including dummy variables for age classes: less than 30 years old; 30-39 years old; and 40-49 years old. The age class that serves as reference for the age dummies corresponds to founders that are 50 years or older). ${ }^{10}$ While older people have had more time to build better networks, identify valuable opportunities, and are more likely to have accumulated capital to finance the startup (Blanchflower and Oswald,

\footnotetext{
10 Entrepreneur age is measured in the year of founding. Using dummy variables for age classes considerably reduces the inevitable high correlation between age and work experience.
} 
1998), evidence shows that the positive effect of age on the probability of success fades as age increases, since older people may be less prone to embark upon the more demanding work schedules required by self-employment, and are closer to retirement (Evans and Leighton, 1989). We group all founders who are 50 years or older into a single age class since several empirical studies suggest that the negative effect of age on survival starts to dominate the positive effect around this age (Rees and Shah, 1986; Carrasco, 1999).

Table 1 displays the main descriptive statistics for each cohort of founders as well as the total sample. The number of startups recorded increased consistently during the period of analysis. This could be partly due to increased coverage of the database. However, since all the firms report their age and the tenure of their employees, it is possible to identify true startups vs. firms that simply show up in the database for the first time. Hence, our sample reflects a true increase in startup activity.

\section{Table 1 about here}

The average age of founders, the number of founders per firm, the proportion of unemployed founders and the proportion of survivors show little variation across the four cohorts. The proportion of previously unemployed ${ }^{11}$ founders is particularly striking, at over $75 \%$ for the whole sample, never falling below $72 \%$ for any of the cohorts.

\footnotetext{
${ }^{11}$ The average length of an unemployment spell in our data is 1.3 years. While the vast majority of individuals who appear 'unemployed' in the Quadros de Pessoal database in fact correspond to the share of the workforce who is without occupation and actively searching for employment, a small minority may be composed of inactive individuals (e.g. people who were once employed but went back to being full time students), or individuals who are employed in industries not covered by the database (e.g. agriculture).
} 
Tables 1A and 1B present separate descriptive statistics for previously unemployed (necessity-based) and previously employed (opportunity-based) founders. The proportion of opportunity-based founders increases from about $22 \%$ in $1995-96$ to about $27 \%$ in 2001-2002. Key statistics appear not to be much different for the two types of founders: they are, on average, about the same age, start similarly sized companies (slightly larger for opportunity-based entrepreneurs) ${ }^{12}$ and form similarly sized venture teams. The survival rate of opportunity-driven founders is a little above average in all cohorts and for the whole sample, while the survival rate for unemployment-driven founders is consistently slightly below average.

\section{Tables $1 \mathrm{~A}$ and $1 \mathrm{~B}$ about here}

Detailed variable definitions plus descriptive statistics for the whole sample (19952002) are presented in Table 2. Spinouts represent about $7 \%$ of the sample, while portfolio entrepreneurs are about $6 \%$.

\section{Table 2 about here}

Table 3 presents the correlation matrix. Correlations between explanatory variables are generally small, with the exception of work experience and industry-specific experience, which are highly positively correlated (correlation coefficient of 0.62 ); however, this correlation does not seem to affect the estimations significantly.

\section{Table 3 about here}

\footnotetext{
${ }^{12}$ During the period under analysis, there was no government support specifically directed at start-ups by the unemployed in Portugal. Support was available equally regardless of employment status.
} 
Assuming that necessity-based entrepreneurship corresponds directly to unemployment-driven entrepreneurship raises some problems, since data are collected on a yearly basis. Firstly, a founder of a new business in year $t$ who was registered as unemployed in year $t-1$ might have found a job in between the data collection time in year $t-1$ and the new business start. Someone in these circumstances is recorded by the data as if he/she were starting the firm following unemployment, when in fact he/she is starting the firm following employment. Likewise, a founder of a new business in year $t$ who was registered as employed at time $t-1$ might have undergone a short spell of unemployment in between the data collection time in year $t-1$ and the new business start, and is therefore erroneously recorded by the data as if he/she were starting the firm following employment. In spite of such limitations, we believe the approach followed here to be advantageous for the study of the research questions investigated in the present paper.

\subsection{Methodology}

We observe firms in the year of entry and again three years later. Our dependent variable (survival) is a dummy that assumes value one if the firm is still operating and the founder is still the owner (or one of the owners) three years after startup, and value zero otherwise. Exit may result from closure or acquisition. However, acquisition is a rare phenomenon in the Portuguese context (Mata et al., 1995) and the overwhelming majority of exits is likely to result from closure.

All variables used refer to the moment of entry, as we are interested in the effect of founding conditions (such as the pre-entry experiences of entrepreneurs) on early survival. The effect of the explanatory variables can then be captured using the Logit 
regression model of the probability of survival. In order to examine the differences in outcomes between opportunity-driven and unemployment-driven entrepreneurs, we estimate separate models for those founders who were previously employed and for those who were previously unemployed. In this way we are able to verify whether the effects of the entrepreneur human capital variables differ according to the type of entrepreneur. $^{13}$

\section{Results}

Logit models for the probability of survival three years after startup are estimated for each cohort separately and for the whole sample. In all estimations the standard errors are clustered at the firm level. The results are, in general, quite comparable, confirming that the models are robust and each of the cohorts displays similar features. Table 4 presents the estimations for a 'reduced' model including both opportunity-based and unemployment-driven founders using only firm-level variables and industry dummies (the controls), and a dummy variable identifying previously employed founders. Coefficients for the estimations using the whole sample are, in general, more significant than coefficients for estimations using each individual cohort, which should be expected given the larger number of observations. The signs of the coefficients for each variable are persistently the same across cohorts and for the whole sample.

\section{Table 4 about here}

\footnotetext{
13 An alternative procedure would be to estimate single models including interaction (moderator) variables corresponding to the product between the employment (opportunity-based) dummy and each of the entrepreneur human capital variables. However, the estimation of separate models for each type of entrepreneur avoids using interaction effects whose interpretation, especially in a Logit framework, is always problematic.
} 
Of particular interest are the coefficients for the Employment variable in Table 4. The expectation is that previously employed (i.e. opportunity-based) founders should be significantly more likely to survive than unemployment-driven ones, but the positive coefficients are only weakly significant for the whole sample and two of the cohorts. Hence, hypothesis $H 1$ is supported only weakly by the data, if at all. This result suggests that differences between opportunity-based and unemployment-driven founders do not necessarily arise directly from the nature or quality of the opportunity being exploited, and are more likely to result from the use of their abilities (i.e. accumulated human capital).

In Tables 5A and 5B we estimate separate models for previously unemployed and previously employed founders, adding the entrepreneurial human capital variables to the mix of explanatory variables in order to test hypothesis $H 2 .{ }^{14}$ The inclusion of the set of variables accounting for entrepreneurial characteristics in Tables $5 \mathrm{~A}$ and $5 \mathrm{~B}$ significantly improves the models. ${ }^{15}$ A model testing the effects of different sources or forms of entrepreneur human capital for the sample as a whole was also estimated, ${ }^{16}$ showing mixed results for the effects of human capital variables. Portfolio entrepreneurs and spinout founders are significantly more likely to survive, confirming our expectations for these two types of entrepreneurial human capital, while other entrepreneurial human capital variables are insignificant. These results suggest that advantages of entrepreneurs who were not unemployed before startup concentrate on

\footnotetext{
${ }^{14}$ A model pooling all entrepreneurs and adding interaction effects between the Employment variable and the human capital variables was estimated, showing significantly positive interaction effects favoring previously employed founders, thus supporting the results of the separate estimations presented here. Results are available from the authors upon request.

15 Tests comparing the Wald statistics for models with and without the variables accounting for entrepreneurial characteristics show that the inclusion of this set of variables significantly improves explanatory power at the $1 \%$ significance level for all cohorts individually and the sample as a whole.

${ }^{16}$ Results are omitted due to lack of space and are available from the authors upon request.
} 
spinout founders and portfolio entrepreneurs, while there seem to be no significant differences in early survival probabilities between unemployment-driven entrepreneurs and previously employed entrepreneurs who are not part of those two specific groups.

\section{Tables 5A, 5B about here}

The effects of both firm-level variables and industry dummies are analogous for both types of founders, suggesting that any differences in performance are likely to originate from entrepreneurial characteristics (human capital). The control variables have, in general, the expected effects, confirming previous findings in the empirical literature. The variable accounting for employee education becomes insignificant when entrepreneur human capital variables are added, which is not surprising since startups are usually small (the average startup size across all cohorts is 4.34 wage earners) and their faith is more likely to hinge on the founders' choices. ${ }^{17}$ Entrepreneurial teams are significantly more likely to survive the critical first years after startup, suggesting that there are tangible and intangible features of entrepreneurial human capital that can be added or matched across the members of the entrepreneurial team, positively influencing startup survival.

The estimations in Table 5B do not include the variables accounting for spinouts and portfolio entrepreneurs, since in these cases the founders were not unemployed before startup. Comparing effects of the other sources of entrepreneurial human capital between opportunity-based and unemployment-driven entrepreneurs provides quite striking results. While the variables accounting for age, gender, and the existence of an entrepreneurial team yield consistent results, the coefficient estimations for

\footnotetext{
${ }^{17}$ Also, recent research finds evidence of a match between founders' and early employees' characteristics and human capital (Baptista et al., 2013).
} 
entrepreneurial human capital variables yield very different results for necessitybased/unemployment-driven (Table 5A) and opportunity-based (Table 5B) founders.

While variables accounting for education levels and specific forms of human capital are generally insignificant (and even display counter-intuitive signs, as is the case of industry experience and managerial experience) for necessity-based/unemploymentdriven entrepreneurs, the same variables are significant and display the expected signs for opportunity-based entrepreneurs. We can therefore claim that our hypothesis $H 2$ is in general supported by the data.

Higher levels of education have a significantly positive impact on the probability of early survival for both types of founders. ${ }^{18}$ However, work experience, industry experience, and managerial experience only contribute significantly to increase the probability of early survival of opportunity-based entrepreneurs (across all cohorts and for the whole sample) and not for necessity-based ones.

Entrepreneurial experience seems to be an important factor in the survival of necessity-based entrepreneurs, but not of opportunity-based ones. This suggests that, in the case of opportunity-based founders, other kinds of pre-entry human capital such as general education and work, industry, and managerial experience can successfully compensate for the lack of entrepreneurial experience in the case of opportunity-driven entrepreneurs, possibly because higher levels of general and specific human capital help founders learn faster about the market, technology, and internal organization, and

\footnotetext{
${ }^{18}$ The completion of a high school degree seems to have a bigger impact when compared with primary education than a university degree, but both are significantly positive across all cohorts and for the complete sample.
} 
provide them with the required networks of contacts regarding sources of finance, prospective customers, and suppliers.

Overall, the results suggest that, while a variety of forms of specific human capital (particularly industry-specific and managerial experience) counterbalance the lack of entrepreneurial experience in opportunity-driven founders, unemployment-driven founders may benefit from accumulated learning that occurred in previous entrepreneurial experiences which might provide them with knowledge about how to sustain a business in the early years, or possibly make them more persistent in the face of poor outcomes.

\section{Concluding Remarks}

This study sought to examine the role played by pre-entry capabilities and human capital associated with the experiences of founders in contributing for the early survival of new businesses, highlighting differences between opportunity based and necessitybased/unemployment-driven entrepreneurs. It can be argued that entrepreneurial characteristics play an especially important role in the critical early years of a startup, when the mission and organization of the firm are being established, and the hiring of key personnel is being carried out.

In summary, the results imply that for entrepreneurs who were employed prior to startup - that is, those more likely to be driven by opportunity discovery - both general and specific forms of entrepreneurial human capital contribute to increase the probability of surviving the critical first three years after startup. However, for 
entrepreneurs who were unemployed prior to startup - and therefore more likely to be starting a firm as an escape from unemployment - only previous entrepreneurial experience seems to increase significantly the probability of early survival. The results also highlight two cases where the chances of early survival are especially strong and significant: spinout founders and portfolio entrepreneurs have consistently greater chances of early survival than other founders.

The creation of new firms involves both opportunity discovery and evaluation, as would-be entrepreneurs decide whether an opportunity can be turned into a business which is sufficiently profitable to offset the opportunity costs involved. Opportunity evaluation and exploitation involves knowledge about demand, technology, organization, customers and suppliers that may be learned by founders prior to entry. The advantages uncovered for spinout founders and portfolio entrepreneurs, as well as the findings that industry-specific and managerial experience matter only for founders who were not unemployed prior to startup, suggest that these are indeed more likely to have engaged in opportunity evaluation and are better equipped for opportunity exploitation, while unemployment-driven entrepreneurs are less likely to search and evaluate opportunities, relying on previous entrepreneurial experience to persevere in the early years after startup.

The specific phenomena of spinouts and portfolio entrepreneurship deserve particular attention in the study of pre-entry capabilities and entrepreneurial human capital. Firstly, spinouts probably incorporate an organizational heritage from the parentcompany, by which founders possibly replicate knowledge, technologies and organizational features learned in the firms they left, which represent the environments 
where they probably discovered their entrepreneurial opportunity (Klepper, 2001; 2007); secondly, portfolio entrepreneurship is likely to provide more network connections and knowledge of potential customers, and a greater ability to overcome financial constraints. In particular, it is likely that for both types of founders the opportunity for the new business was discovered and evaluated in the environment of the previous business.

We believe these results hold meaningful implications for both theory building and policy-making. Pre-entry knowledge of entrepreneurs is a significant determinant of early survival, but mostly in the cases where founders actually bore an opportunity cost (leaving their previous employment) to pursue an entrepreneurial opportunity. In these cases, pre-entry knowledge associated with general and specific human capital helps discover and evaluate opportunities, set up the business, and endure the critical first years after founding, possibly by facilitating more cumulative learning about the market. It can be argued that these entrepreneurs are the ones more likely to grow their businesses, create jobs, and contribute to general economic growth. These results are important for those in charge of private and public institutions dedicated to assist the development of entrepreneurial startups. While aiding startups by the unemployed may be a socially important endeavor, policy makes should not expected these startups to survive in the long term and contribute significantly to employment growth. In contrast, aiding those founders who face an opportunity cost to found their businesses is more likely to provide positive results. 


\section{References}

Acs ZJ, Arenius P, Hay M, Minniti M. (Eds.) 2005. Global Entrepreneurship Monitor2004 Summary Report. Babson College \& London Business School.

Agarwal R, Echambadi R, Franco AM, Sarkar MB. 2004. Knowledge Transfer through Inheritance: Spinout Generation, Development, and Survival. Academy of Management Journal 47:501-522.

Albrecht JW, Edin P, Sundström M, Vroman SB. 1999. Career interruptions and subsequent earnings: a reexamination using Swedish data. Journal of Human Resources 34: 294-311.

Alvarez SA, Busenitz LW. 2001. The Entrepreneurship of Resource-based Theory. Journal of Management 27: 755-775.

Amaral AM, Baptista R, Lima F. 2011. Serial Entrepreneurship: the impact of human capital on time to re-entry. Small Business Economics, 37(1): 1-21.

Andersson P, Wadensjö E. 2006. Do the Unemployed Become Successful Entrepreneurs? A Comparison between the Unemployed, Inactive and WageEarners. International Journal of Manpower, 28(7): 604-626.

Barnett WP, Swanson A-N, Sorenson O. 2003. Asymmetric selection among organizations. Industrial and Corporate Change, 12: 673-695.

Baptista R, Lima F, Preto MT. 2013. Entrepreneurial Skills and Workers' Wages in Small Firms. Small Business Economics 40: 309-323.

Barney J, Busenitz LW, Fiet JO, and Moesel DD. 1996. New venture teams' assessment of learning assistance from venture capital firms. Journal of Business Venturing, 11: $257-272$.

Blanchflower D, Oswald A. 1998. What Makes an Entrepreneur? Journal of Labor Economics 16: 26-60.

Bosma N, van Praag M, Thurik R, de Wit G. 2004. The Value of Human and Social Capital Investments for the Business Performance of Startups. Small Business Economics 23: 227-236.

Brüderl J, Preisendörfer P, Ziegler R. 1992. Survival Chances of Newly Founded Organizations. American Sociological Review 57: 227-242.

Busenitz LG, Page West III G, Shepherd D, Nelson T, Chandler GN, Zacharakis A. 2003. Entrepreneurship Research in Emergence: Past Trends and Future Directions. Journal of Management 29(3): 285-308.

Carrasco R. 1999. Transitions to and from Self-employment in Spain. Oxford Bulletin of Economics and Statistics 61: 315-41.

Colombo M, Delmastro M, Grilli L. 2004. Entrepreneurs' human capital and the startup size of new technology-based firms. International Journal of Industrial Organization 22: 1183-1211.

Conner KR, Prahalad, CK. 1996. A Resource Based Theory of the Firm: Knowledge versus Opportunism. Organization Science 7(5): 477-501. 
Cooper AC, Gimeno-Gascon FJ, Woo CY. 1994. Initial Human and Financial Capital as Predictors of New Venture Performance. Journal of Business Venturing 9: 371395.

Dahl M, Reichstein T. 2007. Are You Experienced? Prior Experience and the Survival of New Organizations. Industry and Innovation 14(5): 497-511.

Eisenhardt KM, Martin JA. 2000. Dynamic Capabilities: What Are They? Strategic Management Journal 21: 1105-1121.

Evans LB, Leighton LS. 1989. Some Empirical Aspects of Entrepreneurship. American Economic Review, 79: 519-535.

Freeman J, Carroll G, Hannan M. 1983. The Liability of Newness - Age Dependence in Organizational Death Rates. American Sociological Review 48: 692-710.

Geroski PA. 1995. What Do We Know About Entry? International Journal of Industrial Organization 13: 421- 440.

Gerosky PA, Mata J, Portugal P. 2010. Founding Conditions and the Survival of New Firms. Strategic Management Journal 31: 510-529.

Grant R. 1996. Toward a knowledge-based theory of the firm. Strategic Management Journal 17: 109-122.

Helfat CE, Lieberman MB. 2002. The Birth of Capabilities: Market Entry and the Importance of Pre-history. Industrial and Corporate Change 11: 725-760.

Jovanovic B. 1982. Selection and Evolution of Industry. Econometrica 50: 649-670.

Klepper S. 2001. Employee Startups in High-Tech Industries. Industrial and Corporate Change 10: 639-674.

Klepper S. 2007. Disagreements, Spinoffs, and the Evolution of Detroit as the Capital of the U.S. Automobile Industry. Management Science 53: 616-631.

Littunen H, Streamer E, Nenonen T. 1998. Survival of Firms over the Critical First Three Years and The Local Environment. Entrepreneurship \& Regional Development 10: 189-202.

Mata J, Portugal P. 2002. The Survival of New Domestic and Foreign-Owned Firms. Strategic Management Journal 23: 323-343.

Mata J, Portugal P, Guimarães P. 1995. The Survival of New plants: Entry Conditions and Post-entry Evolution. International Journal of Industrial Organization 13: 459-482.

McGrath RG, Macmillan I. 2000. The Entrepreneurial Mindset. Harvard Business School Press: Boston, MA.

Mincer J, Ofek H. 1982. Interrupted Work Careers: Depreciation and Restoration of Human Capital. Journal of Human Resources 17(1): 3-24.

Neuman S, Weiss A. 1995. On the Effects of Schooling Vintage on Experience-earnings Profiles: Theory and Evidence. European Economic Review 39: 943-955. 
Parker SC. 2013. Do Serial Entrepreneurs Run Successively Better-performing Businesses? Journal of Business Venturing 28(5):652-666

Peteraf MA. 1993. The Cornerstones of Competitive Advantage: a Resource-based View. Strategic Management Journal 14: 179-191.

Pfeiffer F, Reize F. 2000. Business Startups by the Unemployed - An Econometric Analysis Based on Firm Data. Labour Economics 7: 629-63.

Quatraro F, Vivarelli M. 2013. Drivers of Entrepreneurship and Post-Entry Performance of Newborn Firms in Developing Countries. IZA Discussion Paper \#7436.

Rees H, Shah A. 1986. An Empirical Analysis of Self-employment in the U.K. Journal of Applied Econometrics 1: 101-108.

Santarelli E, Vivarelli M. 2007. Entrepreneurship and the Process of Firms' Entry, Survival and Growth. Industrial and Corporate Change 16: 455-488.

Shane S. 2000. Prior Knowledge and the Discovery of Entrepreneurial Opportunities. Organization Science 11: 448-469.

Shane S, Venkataraman S. 2000. The Promise of Entrepreneurship as a Field of Research. Academy of Management Review 25: 217-226.

Sluis JV, Praag, MV, Vijverberg W. 2005. Entrepreneurship, Selection and Performance: A Meta-analysis of the Impact of Education in Less Developed Countries. World Bank Economic Review 19: 225-261

Stam E, Audretsch DB, Meijaard. 2008. Renascent entrepreneurship. Journal of Evolutionary Economics 18: 493-507.

Stam E, Thurik R, van der Zwan P. 2010. Entrepreneurial exit in real and imagined markets. Industrial and Corporate Change 19: 1109-1139.

Storey DJ. 1991. The Birth of New Firms - Does Unemployment Matter? A Review of the Evidence. Small Business Economics 3: 167-78.

Storey DJ, Jones AM. 1987. New Firm Formation - A Labor Market Approach to Industrial Entry. Scottish Journal of Political Economy 34: 37-51.

Ucbasaran D, Wright M, Westhead P. 2003. A Longitudinal Study of Habitual Entrepreneurs: Starters and Acquirers. Entrepreneurship \& Regional Development 15: 207-228.

Teece, DJ, Pisano G, Shuen A. 1997. Dynamic Capabilities and Strategic Management. Strategic Management Journal 18:509-533.

Ucbasaran D, Wright M, Westhead P. 2008. Opportunity identification and pursuit does an entrepreneur's human capital matter? Small Business Economics 30: 153-173.

Vivarelli M. 2007. Entry and Post-Entry Performance of Newborn Firms. London: Routledge. 
Table 1: Descriptive statistics for the four cohorts of founders

\begin{tabular}{|l|r|r|r|r|r|r|}
\hline Cohorts & $\begin{array}{c}\text { No. of } \\
\text { Founders }\end{array}$ & $\begin{array}{c}\text { Avg. } \\
\text { Startup } \\
\text { Size }\end{array}$ & $\begin{array}{c}\text { Avg. } \\
\text { Age of } \\
\text { Founder }\end{array}$ & $\begin{array}{c}\text { No. of } \\
\text { Founders } \\
\text { per Firm }\end{array}$ & $\begin{array}{c}\text { Percentage of } \\
\text { Unemployed } \\
\text { Founders }\end{array}$ & $\begin{array}{c}\text { Percentage of } \\
\text { Founders } \\
\text { Surviving after } \\
\text { three years }\end{array}$ \\
\hline $\mathbf{1 9 9 5 - 1 9 9 6}$ & 28772 & 4.70 & 36.28 & 1.38 & 77.38 & 74.69 \\
\hline $\mathbf{1 9 9 7 - 1 9 9 8}$ & 32180 & 4.57 & 36.15 & 1.37 & 78.51 & 75.99 \\
\hline $\mathbf{1 9 9 9 - 2 0 0 0}$ & 44749 & 3.95 & 35.88 & 1.37 & 77.68 & 72.50 \\
\hline $\mathbf{2 0 0 1 - 2 0 0 2}$ & 64217 & 4.32 & 38.72 & 1.39 & 72.02 & 79.07 \\
\hline Total & 169918 & 4.34 & 37.07 & 1.38 & 75.65 & 76.01 \\
\hline
\end{tabular}

Table 1A: Descriptive statistics for the four cohorts of previously unemployed founders

\begin{tabular}{|l|r|r|r|r|r|}
\hline Cohorts & $\begin{array}{c}\text { No. of } \\
\text { Founders }\end{array}$ & $\begin{array}{c}\text { Avg. } \\
\text { Startup } \\
\text { Size }\end{array}$ & $\begin{array}{c}\text { Avg. Age of } \\
\text { Founder }\end{array}$ & $\begin{array}{c}\text { No. of } \\
\text { Founders } \\
\text { per Firm }\end{array}$ & $\begin{array}{c}\text { Percentage of } \\
\text { Founders Surviving } \\
\text { after three years }\end{array}$ \\
\hline $\mathbf{1 9 9 5 - 1 9 9 6}$ & 22263 & 4.37 & 36.13 & 1.36 & 74.38 \\
\hline $\mathbf{1 9 9 7 - 1 9 9 8}$ & 25266 & 4.23 & 35.97 & 1.36 & 75.49 \\
\hline $\mathbf{1 9 9 9 - 2 0 0 0}$ & 34759 & 3.61 & 35.93 & 1.36 & 71.86 \\
\hline $\mathbf{2 0 0 1 - 2 0 0 2}$ & 46248 & 4.10 & 39.07 & 1.37 & 78.09 \\
\hline Total & 128536 & 4.04 & 37.10 & 1.36 & 75.25 \\
\hline
\end{tabular}

Table 1B: Descriptive statistics for the four cohorts of previously employed founders

\begin{tabular}{|l|r|r|r|r|r|}
\hline Cohorts & $\begin{array}{c}\text { No. of } \\
\text { Founders }\end{array}$ & $\begin{array}{c}\text { Avg. } \\
\text { Startup } \\
\text { Size }\end{array}$ & $\begin{array}{c}\text { Avg. Age of } \\
\text { Founder }\end{array}$ & $\begin{array}{c}\text { No. of } \\
\text { Founders } \\
\text { per Firm }\end{array}$ & $\begin{array}{c}\text { Percentage of } \\
\text { Founders Surviving } \\
\text { after three years }\end{array}$ \\
\hline $\mathbf{1 9 9 5 - 1 9 9 6}$ & 6509 & 6.01 & 36.80 & 1.43 & 75.74 \\
\hline $\mathbf{1 9 9 7 - 1 9 9 8}$ & 6914 & 6.04 & 36.79 & 1.41 & 77.80 \\
\hline $\mathbf{1 9 9 9 - 2 0 0 0}$ & 9990 & 5.29 & 35.67 & 1.40 & 74.72 \\
\hline $\mathbf{2 0 0 1 - 2 0 0 2}$ & 17969 & 4.98 & 37.83 & 1.45 & 81.57 \\
\hline Total & 41382 & 5.39 & 36.97 & 1.43 & 78.37 \\
\hline
\end{tabular}


Table 2: Variable definitions and descriptive statistics

\begin{tabular}{|c|c|c|c|c|c|c|}
\hline Variable & Definition & $\begin{array}{l}\text { No. } \\
\text { Obs* }\end{array}$ & Mean & $\begin{array}{l}\text { Std. } \\
\text { Dev. }\end{array}$ & Min & Max \\
\hline Survival & $\begin{array}{l}\text { Variable }=1 \text { if both firm and founder remain active } \\
\text { three years after founding, and } 0 \text { otherwise }\end{array}$ & 169918 & 0.76 & 0.43 & 0 & 1 \\
\hline Log Size & $\begin{array}{l}\text { Log of the number of employees of the firm at } \\
\text { founding }\end{array}$ & 169918 & 1.23 & 0.73 & 0 & 6.46 \\
\hline Emp Education & $\begin{array}{l}\text { Proportion of employees that are university } \\
\text { graduates at founding }\end{array}$ & 165354 & 0.016 & 0.11 & 0 & 1 \\
\hline Age below 30 & $\begin{array}{l}\text { Variable }=1 \text { if founder is } 29 \text { years of age or } \\
\text { younger at the time of founding, and } 0 \text { otherwise }\end{array}$ & 161582 & 0.20 & 0.40 & 0 & 1 \\
\hline Age 30-39 & $\begin{array}{l}\text { Variable }=1 \text { if founder is between } 30 \text { and } 39 \text { years } \\
\text { of age at the time of founding, and } 0 \text { otherwise }\end{array}$ & 161582 & 0.36 & 0.48 & 0 & 1 \\
\hline Age 40-49 & $\begin{array}{l}\text { Variable }=1 \text { if founder is between } 40 \text { and } 49 \text { years } \\
\text { of age at the time of founding, and } 0 \text { otherwise }\end{array}$ & 161582 & 0.27 & 0.44 & 0 & 1 \\
\hline Gender & Variable $=1$ if founder is female, and 0 if it is male & 169918 & 0.28 & 0.45 & 0 & 1 \\
\hline University Grad & $\begin{array}{l}\text { Variable }=1 \text { if founder is a university graduate at } \\
\text { the time of founding, and } 0 \text { otherwise }\end{array}$ & 167838 & 0.08 & 0.28 & 0 & 1 \\
\hline $\begin{array}{l}\text { High School } \\
\text { Grad }\end{array}$ & $\begin{array}{l}\text { Variable }=1 \text { if founder is a high school graduate at } \\
\text { the time of founding, and } 0 \text { otherwise }\end{array}$ & 167838 & 0.17 & 0.38 & 0 & 1 \\
\hline Work Exp & $\begin{array}{l}\text { Number of years since founder entered the labor } \\
\text { market }\end{array}$ & 169918 & 1.58 & 2.20 & 0 & 8 \\
\hline Spinout & $\begin{array}{l}\text { Variable }=1 \text { if founder was working in an } \\
\text { incumbent of the startup's industry in the year } \\
\text { before founding, and } 0 \text { otherwise }\end{array}$ & 169918 & 0.07 & 0.25 & 0 & 1 \\
\hline Industry Exp & $\begin{array}{l}\text { Number of years founder worked in the startup's } \\
\text { industry prior to founding }\end{array}$ & 169918 & 1.31 & 1.98 & 0 & 8 \\
\hline Managerial Exp & $\begin{array}{l}\text { Number of years the founder worked in one of the } \\
\text { top three hierarchical levels listed in the data set }\end{array}$ & 169918 & 0.52 & 1.28 & 0 & 8 \\
\hline Entrep Exp & $\begin{array}{l}\text { Variable = } 1 \text { if individual has founded at least one } \\
\text { firm in the past, but was not a business owner at } \\
\text { founding, and } 0 \text { otherwise }\end{array}$ & 169918 & 0.16 & 0.37 & 0 & 1 \\
\hline Portfolio & $\begin{array}{l}\text { Variable }=1 \text { if individual owned at least another } \\
\text { business at founding, and } 0 \text { otherwise }\end{array}$ & 167838 & 0.06 & 0.38 & 0 & 1 \\
\hline Entrep Team & $\begin{array}{l}\text { Variable }=1 \text { if firm is being founded by more than } \\
\text { one individual, and } 0 \text { otherwise }\end{array}$ & 169918 & 0.51 & 0.50 & 0 & 1 \\
\hline Employment & $\begin{array}{l}\text { Variable }=1 \text { if founder was employed in the year } \\
\text { before founding }\end{array}$ & 169918 & 0.24 & 0.43 & 0 & 1 \\
\hline Year Dummies & \multicolumn{6}{|c|}{$\begin{array}{l}\text { Year dummies for cohort estimations: Variables }=1 \text { for firms founded in } 1995 \text { and } 0 \\
\text { otherwise; } 1997 \text { and } 0 \text { otherwise; } 1999 \text { and } 0 \text { otherwise; } 2001 \text { and } 0 \text { otherwise }\end{array}$} \\
\hline $\begin{array}{l}\text { Industry } \\
\text { Dummies }\end{array}$ & \multicolumn{6}{|l|}{ Industry dummies at the three-digit level } \\
\hline
\end{tabular}

${ }^{19}$ As pointed out earlier, data report each individual's position in the firm's hierarchy according to a specific code. There are eight categories or hierarchical levels. These are, from lower to higher: apprentices, interns and trainees; non-skilled professionals; semi-skilled professionals; skilled professionals; higher-skilled professionals; supervisors and team leaders; intermediary managers: and top managers. 
Table 3: Correlation matrix

\begin{tabular}{|c|c|c|c|c|c|c|c|c|c|c|c|c|c|c|c|c|}
\hline & 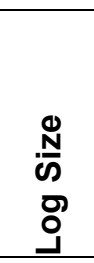 & 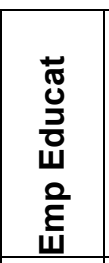 & 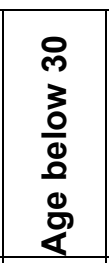 & 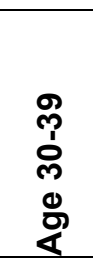 & 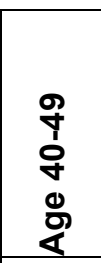 & $\begin{array}{l}\frac{ \pm}{0} \\
\frac{0}{0} \\
0 \\
0\end{array}$ & 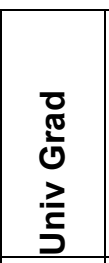 & 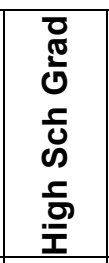 & $\begin{array}{l}\stackrel{0}{x} \\
\text { ய } \\
\stackrel{x}{0} \\
\vdots \\
3\end{array}$ & 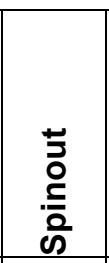 & 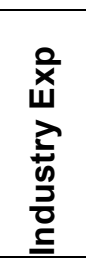 & 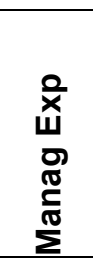 & 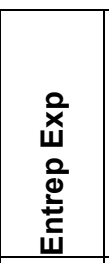 & $\begin{array}{l}\stackrel{ }{0} \\
\stackrel{0}{ \pm} \\
0 \\
0\end{array}$ & 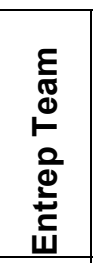 & 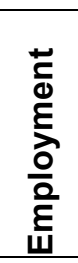 \\
\hline Log Size & 1.00 & & & & & & & & & & & & & & & \\
\hline Emp Educat & 0.04 & 1.00 & & & & & & & & & & & & & & \\
\hline Age below 30 & 0.00 & 0.00 & 1.00 & & & & & & & & & & & & & \\
\hline Age 30-39 & 0.02 & 0.01 & \begin{tabular}{|l|}
-0.38 \\
\end{tabular} & 1.00 & & & & & & & & & & & & \\
\hline Age 40-49 & 0.01 & $\mid-0.01$ & \begin{tabular}{|l|}
-0.30 \\
\end{tabular} & -0.46 & 1.00 & & & & & & & & & & & \\
\hline Gender & -0.04 & 0.00 & 0.01 & 0.02 & 0.00 & 1.00 & & & & & & & & & & \\
\hline Univ Grad & -0.03 & 0.24 & 0.04 & 0.03 & -0.03 & 0.04 & 1.00 & & & & & & & & & \\
\hline High Sch Grad & -0.03 & 0.02 & 0.12 & 0.06 & -0.07 & 0.04 & -0.13 & 1.00 & & & & & & & & \\
\hline Work Exp & 0.05 & 0.01 & 0.01 & 0.14 & -0.03 & $\mid-0.01$ & -0.01 & 0.05 & 1.00 & & & & & & & \\
\hline Spinout & 0.10 & $\mid-0.01$ & 0.07 & 0.03 & -0.04 & 0.00 & -0.01 & 0.00 & 0.37 & 1.00 & & & & & & \\
\hline Industry Exp & 0.15 & -0.01 & \begin{tabular}{|l|}
-0.07 \\
\end{tabular} & 0.07 & 0.01 & -0.05 & -0.04 & 0.00 & 0.62 & 0.43 & 1.00 & & & & & \\
\hline Manag Exp & 0.12 & 0.07 & \begin{tabular}{|l|}
-0.14 \\
\end{tabular} & -0.02 & 0.08 & -0.07 & 0.12 & 0.02 & 0.18 & 0.04 & 0.39 & 1.00 & & & & \\
\hline Entrep Exp & 0.13 & 0.01 & \begin{tabular}{|l|}
-0.13 \\
\end{tabular} & -0.04 & 0.07 & -0.07 & 0.00 & -0.01 & -0.10 & -0.06 & 0.33 & 0.51 & 1.00 & & & \\
\hline \begin{tabular}{|l|} 
Portfolio \\
\end{tabular} & 0.04 & 0.04 & \begin{tabular}{|l|}
-0.04 \\
\end{tabular} & -0.01 & 0.02 & -0.03 & 0.05 & 0.02 & -0.02 & \begin{tabular}{|l|}
-0.02 \\
\end{tabular} & 0.04 & 0.17 & 0.20 & 1.00 & & \\
\hline Entrep Team & 0.34 & \begin{tabular}{|l|}
-0.01 \\
\end{tabular} & 0.04 & 0.01 & -0.03 & 0.03 & \begin{tabular}{|l|}
-0.04 \\
\end{tabular} & -0.01 & 0.06 & 0.07 & 0.05 & -0.02 & \begin{tabular}{|l|}
-0.02 \\
\end{tabular} & 0.05 & 1.00 & \\
\hline Employment & 0.14 & 0.03 & \begin{tabular}{|c|}
-0.02 \\
\end{tabular} & 0.04 & 0.02 & $\mid-0.08$ & $\mid-0.05$ & $\mid-0.02$ & 0.14 & 1.00 & 0.37 & 0.40 & \begin{tabular}{|l|}
-0.11 \\
\end{tabular} & 1.00 & 0.32 & 1.00 \\
\hline
\end{tabular}


Published in: Small Business Economics 42(4):831-847, 2014.

\begin{tabular}{|l|l|r|r|r|r|}
\hline \multicolumn{7}{|c|}{ Table 4: Logit estimates for survival including firm characteristics and } \\
industry dummies \\
\hline & $\begin{array}{c}\text { All } \\
\text { Years }\end{array}$ & $1995-96$ & $1997-98$ & $1999-00$ & $2001-02$ \\
\hline Log Size & $0.51^{* * *}$ & $0.39^{* * *}$ & $0.49^{* * *}$ & $0.45^{* * *}$ & $0.59^{* * *}$ \\
\hline & {$[0.00]$} & {$[0.00]$} & {$[0.00]$} & {$[0.00]$} & {$[0.00]$} \\
\hline Emp Education & $0.25^{* * *}$ & 0.12 & 0.21 & 0.12 & 0.23 \\
\hline & {$[0.00]$} & {$[0.577]$} & {$[0.212]$} & {$[0.332]$} & {$[0.035]$} \\
\hline Employment & $0.16^{*}$ & $0.13^{*}$ & 0.13 & $0.14^{*}$ & $0.14^{* *}$ \\
\hline & {$[0.086]$} & {$[0.099]$} & {$[0.720]$} & {$[0.699]$} & {$[0.576]$} \\
\hline Constant & 2.19 & 1.60 & 1.70 & 1.71 & 1.75 \\
\hline & {$[0.00]$} & {$[0.00]$} & {$[0.00]$} & {$[0.00]$} & {$[0.00]$} \\
\hline Year Dummies & Yes & Yes & Yes & Yes & Yes \\
\hline Industry Dummies & Yes & Yes & Yes & Yes & Yes \\
\hline Number of Entrepreneurs & 169918 & 28689 & 32070 & 44661 & 64069 \\
\hline Number of Clustered Firms & 123324 & 20814 & 23372 & 32624 & 46213 \\
\hline Wald chi2 & 1422.87 & 344.02 & 421.03 & 581.51 & 658.15 \\
\hline Prob>chi2 & 0 & 0 & 0 & 0 & 0 \\
\hline $\begin{array}{l}\left.\text { P-values are in brackets. }{ }^{*}\right) \text { significant at } 10 \% \text { level, } \\
\text { level. }\end{array}$ & (**)significant at $5 \%$ level, $\left.{ }^{* * *}\right)$ significant at $1 \%$ \\
\hline
\end{tabular}




\begin{tabular}{|c|c|c|c|c|c|}
\hline \multicolumn{6}{|c|}{$\begin{array}{l}\text { Table 5A: Logit estimates for survival of necessity-based entrepreneurs including } \\
\text { entrepreneur characteristics, firm characteristics, and industry dummies }\end{array}$} \\
\hline & All Years & $1995-96$ & 1997-98 & $1999-00$ & 2001-02 \\
\hline \multirow{2}{*}{ Log Size } & $0.44^{* * *}$ & $0.30^{* * *}$ & $0.41^{* * *}$ & $0.38^{* * *}$ & $0.55^{\star * *}$ \\
\hline & {$[0.00]$} & {$[0.00]$} & {$[0.00]$} & {$[0.00]$} & {$[0.00]$} \\
\hline \multirow[t]{2}{*}{ Emp Education } & 0.06 & 0.06 & -0.04 & 0.01 & 0.14 \\
\hline & {$[0.462]$} & {$[0.793]$} & {$[0.834]$} & {$[0.96]$} & [0.294] \\
\hline \multirow[t]{2}{*}{ Age below 30} & $-0.20^{\star * *}$ & $-0.12^{* *}$ & $-0.15^{* * \star}$ & $-0.24^{* * *}$ & $-0.25^{\star * *}$ \\
\hline & [0.00] & {$[0.038]$} & {$[0.009]$} & {$[0.00]$} & {$[0.00]$} \\
\hline \multirow[t]{2}{*}{ Age 30-39 } & -0.01 & 0.08 & 0.02 & -0.03 & -0.06 \\
\hline & {$[0.668]$} & {$[0.153]$} & {$[0.758]$} & {$[0.488]$} & [0.11] \\
\hline \multirow[t]{2}{*}{ Age 40-49 } & $0.05^{* *}$ & 0.04 & 0.07 & 0.03 & $0.07^{* *}$ \\
\hline & {$[0.018]$} & {$[0.483]$} & {$[0.164]$} & {$[0.542]$} & {$[0.045]$} \\
\hline \multirow[t]{2}{*}{ Gender } & $-0.08^{* * *}$ & $-0.11^{* * *}$ & -0.06 & $-0.13^{* * *}$ & -0.04 \\
\hline & {$[0.00]$} & {$[0.004]$} & {$[0.127]$} & {$[0.00]$} & [0.159] \\
\hline \multirow[t]{2}{*}{ University Grad } & 0.06 & $0.17^{*}$ & 0.03 & 0.04 & 0.04 \\
\hline & {$[0.176]$} & {$[0.095]$} & {$[0.723]$} & [0.499] & [0.484] \\
\hline \multirow[t]{2}{*}{ High School Grad } & 0.01 & 0.03 & 0.02 & 0.03 & $0.08^{* *}$ \\
\hline & {$[0.722]$} & {$[0.621]$} & {$[0.637]$} & [0.491] & {$[0.05]$} \\
\hline \multirow[t]{2}{*}{ Work Exp } & 0.002 & -0.04 & -0.001 & 0.03 & 0.004 \\
\hline & [0.831] & {$[0.143]$} & {$[0.956]$} & {$[0.084]$} & [0.711] \\
\hline \multirow[t]{2}{*}{ Industry Exp } & -0.002 & -0.01 & -0.01 & -0.01 & 0.01 \\
\hline & {$[0.507]$} & {$[0.462]$} & {$[0.573]$} & {$[0.568]$} & [0.634] \\
\hline \multirow[t]{2}{*}{ Managerial Exp } & $-0.02^{*}$ & 0.03 & 0.02 & -0.03 & $-0.05^{*}$ \\
\hline & {$[0.091]$} & {$[0.314]$} & {$[0.509]$} & {$[0.096]$} & [0.084] \\
\hline \multirow[t]{2}{*}{ Entrep Exp } & $0.09^{* * *}$ & 0.05 & 0.01 & $0.15^{\star * *}$ & $0.18^{\star * \star}$ \\
\hline & {$[0.004]$} & {$[0.465]$} & {$[0.881]$} & {$[0.012]$} & [0.002] \\
\hline \multirow[t]{2}{*}{ Entrep Team } & $0.37^{* * *}$ & $0.35^{\star \star *}$ & $0.44^{* * *}$ & $0.46^{* * *}$ & $0.27^{* * *}$ \\
\hline & {$[0.00]$} & {$[0.00]$} & {$[0.00]$} & {$[0.00]$} & [0.00] \\
\hline \multirow[t]{2}{*}{ Constant } & $1.24^{* * *}$ & $1.18^{\star * *}$ & $1.16^{\star * \star}$ & $1.29^{* * *}$ & $1.22^{* * *}$ \\
\hline & {$[0.00]$} & {$[0.00]$} & {$[0.00]$} & {$[0.00]$} & {$[0.00]$} \\
\hline Year Dummies & Yes & Yes & Yes & Yes & Yes \\
\hline Industry Dummies & Yes & Yes & Yes & Yes & Yes \\
\hline Number of Entrepreneurs & 119506 & 20415 & 22382 & 31159 & 45091 \\
\hline Number of Clustered Firms & 92725 & 15725 & 17276 & 24026 & 35353 \\
\hline Wald chi2 & 3628.06 & 534.56 & 647.26 & 1020.1 & 1835.5 \\
\hline Prob>chi2 & 0 & 0 & 0 & 0 & 0 \\
\hline
\end{tabular}




\begin{tabular}{|c|c|c|c|c|c|}
\hline \multicolumn{6}{|c|}{$\begin{array}{l}\text { Table 5B: Logit estimates for survival of opportunity-based entrepreneurs including } \\
\text { entrepreneur characteristics, firm characteristics, and industry dummies }\end{array}$} \\
\hline & All Years & 1995-96 & 1997-98 & $1999-00$ & 2001-02 \\
\hline \multirow[t]{2}{*}{ Log Size } & $0.40^{* * *}$ & $0.27^{\star * *}$ & $0.33^{* * *}$ & $0.29^{\star \star \star}$ & $0.55^{\star * *}$ \\
\hline & {$[0.00]$} & {$[0.00]$} & {$[0.00]$} & {$[0.00]$} & {$[0.00]$} \\
\hline \multirow[t]{2}{*}{ Emp Education } & 0.14 & -0.40 & 0.83 & -0.23 & 0.27 \\
\hline & {$[0.323]$} & {$[0.363]$} & {$[0.099]$} & {$[0.409]$} & [0.179] \\
\hline \multirow[t]{2}{*}{ Age below 30} & $-0.12^{* *}$ & 0.13 & 0.13 & $-0.26^{* *}$ & $-0.26^{* * *}$ \\
\hline & {$[0.017]$} & {$[0.303]$} & [0.303] & {$[0.016]$} & [0.001] \\
\hline \multirow[t]{2}{*}{ Age $30-39$} & $0.02^{* \star *}$ & 0.14 & 0.15 & 0.01 & 0.08 \\
\hline & {$[0.002]$} & {$[0.007]$} & {$[0.192]$} & {$[0.928]$} & {$[0.247]$} \\
\hline \multirow[t]{2}{*}{ Age $40-49$} & $0.08^{* \star \star}$ & 0.15 & $0.20^{*}$ & 0.06 & 0.04 \\
\hline & {$[0.001]$} & {$[0.169]$} & {$[0.094]$} & {$[0.577]$} & [0.573] \\
\hline \multirow[t]{2}{*}{ Gender } & $-0.11^{* \star \star}$ & $-0.21^{* \star *}$ & -0.12 & $-0.13^{*}$ & $-0.09^{*}$ \\
\hline & {$[0.00]$} & {$[0.01]$} & {$[0.163]$} & {$[0.066]$} & [0.068] \\
\hline \multirow[t]{2}{*}{ University Grad } & $0.04^{* * *}$ & $0.01^{* * *}$ & $0.021^{* * *}$ & $0.022^{*}$ & $0.06^{* *}$ \\
\hline & {$[0.001]$} & {$[0.002]$} & {$[0.002]$} & {$[0.08]$} & {$[0.004]$} \\
\hline \multirow[t]{2}{*}{ High School Grad } & $0.10^{* *}$ & $0.05^{\star \star}$ & $0.11^{* *}$ & $0.06^{* * *}$ & $0.11^{* *}$ \\
\hline & {$[0.011]$} & {$[0.033]$} & {$[0.024]$} & {$[0.002]$} & [0.044] \\
\hline \multirow[t]{2}{*}{ Spinout } & $0.11^{* * *}$ & $0.17^{* * *}$ & $0.15^{* * *}$ & $0.11^{* *}$ & $0.10^{* * *}$ \\
\hline & {$[0.007]$} & {$[0.009]$} & {$[0.007]$} & {$[0.02]$} & [0.001] \\
\hline \multirow[t]{2}{*}{ Work Exp } & $0.04^{\star * \star}$ & 0.02 & $0.05^{* \star *}$ & $0.03^{\star \star \star}$ & $0.04^{\star * *}$ \\
\hline & {$[0.00]$} & {$[0.16]$} & {$[0.002]$} & {$[0.012]$} & {$[0.00]$} \\
\hline \multirow[t]{2}{*}{ Industry Exp } & $0.05^{* * *}$ & $0.04^{* * *}$ & $0.06^{* * *}$ & $0.05^{\star * *}$ & $0.05^{\star \star *}$ \\
\hline & {$[0.00]$} & {$[0.016]$} & {$[0.002]$} & {$[0.001]$} & {$[0.00]$} \\
\hline \multirow[t]{2}{*}{ Managerial Exp } & $0.02^{* * *}$ & $0.02^{* *}$ & $0.02^{* * *}$ & $0.02^{* *}$ & $0.02^{* *}$ \\
\hline & {$[0.01]$} & {$[0.04]$} & {$[0.008]$} & {$[0.018]$} & [0.011] \\
\hline \multirow[t]{2}{*}{ Entrep Exp } & 0.01 & 0.04 & 0.02 & 0.07 & 0.03 \\
\hline & {$[0.887]$} & {$[0.676]$} & {$[0.85]$} & {$[0.409]$} & [0.67] \\
\hline \multirow[t]{2}{*}{ Portfolio } & $0.25^{* * *}$ & $0.14^{\star * *}$ & 0.16 & $0.32^{* *}$ & $0.27^{* * *}$ \\
\hline & {$[0.00]$} & {$[0.002]$} & {$[0.378]$} & {$[0.043]$} & [0.001] \\
\hline \multirow[t]{2}{*}{ Entrep Team } & $0.37^{* * *}$ & $0.31^{* * *}$ & $0.43^{* * *}$ & $0.48^{* * *}$ & $0.31^{* \star *}$ \\
\hline & {$[0.00]$} & {$[0.00]$} & {$[0.00]$} & {$[0.00]$} & {$[0.00]$} \\
\hline \multirow[t]{2}{*}{ Constant } & $1.05^{\star * *}$ & $0.97^{* \star *}$ & $1.32^{* * *}$ & $1.35^{\star * *}$ & $0.78^{* \star *}$ \\
\hline & {$[0.00]$} & {$[0.014]$} & {$[0.014]$} & {$[0.00]$} & {$[0.00]$} \\
\hline Year Dummies & Yes & Yes & Yes & Yes & Yes \\
\hline Industry Dummies & Yes & Yes & Yes & Yes & Yes \\
\hline Number of Entrepreneurs & 35917 & 5148 & 5198 & 7535 & 17535 \\
\hline Number of Clustered Firms & 29367 & 4172 & 4250 & 6209 & 14341 \\
\hline Wald chi2 & 1300.3 & 182.66 & 237.09 & 301.55 & 841.88 \\
\hline Prob>chi2 & 0 & 0 & 0 & 0 & 0 \\
\hline
\end{tabular}

